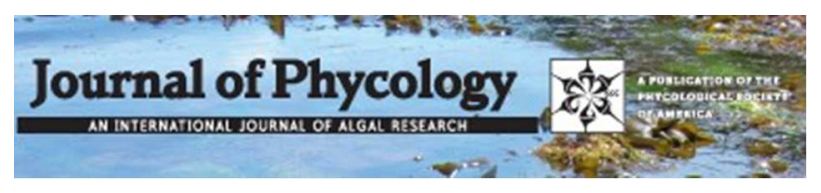

\title{
Contrasting patterns of population structure and demographic history in cryptic species of Bostrychia intricata (rhodomelaceae, rhodophyta) from New Zealand
}

\begin{tabular}{|r|l|}
\hline Journal: & Journal of Phycology \\
\hline Manuscript ID: & JPY-14-248-ART \\
\hline Manuscript Type: & Regular Article \\
\hline Date Submitted by the Author: & 16 -Dec-2014 \\
\hline Complete List of Authors: & $\begin{array}{l}\text { Muangmai, Narongrit; Victoria University of Wellington, } \\
\text { Fraser, Ceridwen; Australian National University, Fenner School of } \\
\text { Environmental and Society } \\
\text { Zuccarello, Giuseppe; Victoria University of Wellington, School of Biological } \\
\text { Sciences }\end{array}$ \\
\hline Keywords: & $\begin{array}{l}\text { cytochrome c oxidase subunit I (COI), demography, phylogeography, } \\
\text { phylogenetics, population genetics, macroalgae, red algae }\end{array}$ \\
\hline &
\end{tabular}


1 CONTRASTING PATTERNS OF POPULATION STRUCTURE AND

2 DEMOGRAPHIC HISTORY IN CRYPTIC SPECIES OF BOSTRYCHIA

3 INTRICATA (RHODOMELACEAE, RHODOPHYTA) FROM NEW

$4 \quad$ ZEALAND $^{1}$

5

6 Narongrit Muangmai ${ }^{2}$

7

8 School of Biological Sciences, Victoria University of Wellington, Wellington 6041,

$9 \quad$ New Zealand

10

11 Ceridwen I. Fraser

12

13 Fenner School of Environmental and Society, ANU College of Medicine, Biology \&

14 Environment, Australian National University, Canberra ACT 2601, Australia

15

16 and

17 Giuseppe C. Zuccarello

18

19 School of Biological Sciences, Victoria University of Wellington, Wellington 6041,

20 New Zealand

21

22 2e-mail: seaweed_53@hotmail.com

23

24 Running title: Phylogeography of B. intricata in New Zealand 


\section{ABSTRACT}

26 Spatial patterns of genetic diversity provide insight into the demography and history

27 of species. Morphologically similar but genetically distinct 'cryptic' species are

28 increasingly being recognized in marine organisms through molecular analyses. Such

29 species are, on closer inspection, often discovered to display contrasting life histories

30 or occasionally minor morphological differences; molecular tools can thus be useful

31 indicators of diversity. Bostrychia intricata, a marine red alga, is widely distributed

32 throughout the Southern Hemisphere, and comprises many cryptic species. We used

33 mitochondrial COI sequences to assess the genetic variation, population genetic

34 structure and demographic history of $B$. intricata in New Zealand. Our results

35 supported the existence of three cryptic species of B. intricata (N2, N4 and N5) in

36 New Zealand. Cryptic species N4 showed a higher genetic diversity and wider

37 distribution than the other two species, which were only found in the North Island and

38 northern South Island. Our analyses showed low to moderate genetic differentiation

39 among eastern North Island populations for cryptic species N2, but high

40 differentiation among North and South Island populations for N4, suggesting different

41 levels of gene flow between populations of these cryptic species. Data also indicated

42 that $\mathrm{N} 2$ has recently undergone population expansion, probably since the Last Glacial

43 Maximum (LGM), while the higher genetic diversity in N4 populations suggests

44 persistence in situ through the LGM. The contrasting population structures and

45 inferred demographic histories of these species highlight that life history can vary

46 greatly even among morphologically indistinguishable taxa.

47

48 Key index words: cytochrome c oxidase subunit I (COI); demography,

49 phylogeography; phylogenetics; population genetics, macroalgae; red algae 
51 Abbreviations: AMOVA, analysis of molecular variation; COI, cytochrome c oxidase

52 I gene; LGM, Last Glacial Maximum; NZ, New Zealand; SAMOVA, spatial analysis

53 of molecular variance

54 


\section{INTRODUCTION}

56 Present-day patterns of genetic diversity can allow inference of dispersal and

57 connectivity among marine populations, and can contribute to our understanding of

58 how historical climatic events, oceanographic conditions and tectonic processes have

59 influenced the evolution and demographic history of marine organisms (Hewitt 2004,

60 Lomolino et al. 2006, Hemmer-Hansen et al. 2007, Fraser et al. 2012). In the high

61 latitudes of the Southern Hemisphere, numerous recent studies have shed light on the

62 diversity, distribution and biogeographic patterns of marine populations (reviewed by

63 Allcock and Strugnell 2012, Fraser et al. 2012). Phylogeographic studies have

64 provided strong evidence for significant population structure in numerous marine

65 organisms (Brante et al. 2012, Le Port and Lavery 2012, Fraser et al. 2013). Such

66 structure can be used to infer how species, and populations within species, have

67 responded to past processes such as climate change. For example, higher genetic

68 diversity in low versus high latitude populations has been interpreted to reflect

69 postglacial recolonisation of higher latitude areas following recession of ice at the

70 LGM (e.g. crustaceans: Nikula et al. 2010; kelp: Fraser et al. 2009, 2010, Macaya and

71 Zuccarello 2010a, b).

72

73 New Zealand (NZ) consists of two main islands, the North and South Islands, which

74 have striking geological and environmental differences, such as northern volcanoes

75 and southern glaciated regions. The complex geographical and oceanographic (Fig

76 S1) systems have resulted in phylogeographic structure in both terrestrial and marine

77 taxa (Ross et al. 2009, Wallis and Trewick 2009). Several phylogeographic studies of

78 marine species have detected deep genetic splits between northern/southern and

79 eastern/western geographical regions (Apte and Gardner 2002, Sharyn et al. 2006, 
80 Ross et al. 2009, 2012) (Fig S1). In contrast, other studies have detected little or no

81 phylogeographic structure around New Zealand, indicating broad population

82 connectivity in some groups (Smith et al. 2002, Waters and Roy 2003). Inconsistency

83 of phylogeographic patterns observed among marine taxa in New Zealand suggests

84 that different species response in different ways, possibly due to species-specific

85 dispersal ability, reproductive strategies or species' and demographic history.

86

87 The phylogeographic structure of several brown seaweeds, e.g., Carpophyllum

maschalocarpum (Turner) Greville, Durvillaea antarctica (Chamisso) Hariot,

Macrocystis pyrifera (Linnaeus) C. Agardh, has previously been investigated in NZ

(Fraser et al. 2009, Macaya and Zuccarello 2010a, Buchanan and Zuccarello 2012).

These studies, which relied largely on data from mitochondrial markers, demonstrated

spatial heterogeneity in genetic diversity among seaweed populations from the North

93 Island, with a transition region between the bottom of the North Island and the top of

94 the South Island (Fraser et al. 2009, Buchanan and Zuccarello 2012). In addition,

95 genetic evidence indicated that the distribution and population connectivity of these

96 buoyant brown seaweeds has been strongly influenced by surface ocean circulation

97 patterns (e.g. Antarctic Circumpolar Currents - ACC) and historical events (e.g., the

98 LGM) (Fraser et al. 2009, Macaya and Zuccarello 2010a, Buchanan and Zuccarello

99 2012, Collins et al. 2010). Whereas population structure and dispersal patterns of

100 brown seaweeds in New Zealand have been quite well studied, research on other

101 groups of seaweed - especially non-buoyant taxa with limited dispersal potential -

102 has been relatively uncommon. Although non-buoyant taxa should theoretically be

103 less capable of long-distance dispersal than robust, buoyant taxa, and might therefore

104 be expected to show stronger phylogeographic structure (Fraser et al. 2013), dispersal 
105 capacity alone is not always a good predictor of population connectivity (Waters et al.

106 2013).

107

108 The genus Bostrychia Montagne is a filamentous red alga of the family

109 Rhodomelaceae, order Ceramiales, and currently contains $\sim 19$ species, which are

110 widely distributed in tropical and temperate regions (King and Puttock 1989,

111 Zuccarello and West 2006). Bostrychia has been used as a model system to study

112 evolution, speciation processes, and population connectivity (review in Zuccarello

113 and West 2011). For example, studies on genetic diversity of Bostrychia radicans

114 (Montagne) Montagne and B. moritziana (Sonder ex Kützing) J. Agardh show that

115 these two morphospecies consist of seven non-interbreeding genealogical lineages,

116 suggesting cryptic species (Zuccarello et al. 1999b; Zuccarello and West 2003), some

117 of which occur in sympatry (Zuccarello and West 2003, Zuccarello et al. 2006,

118 Zuccarello et al. 2011). However, while the phylogenetic diversity and

119 phylogeography of the warm-temperate Bostrychia species have been well studied,

120 diversity and distribution patterns of Bostrychia species endemic to the Southern

121 Hemisphere are still poorly documented.

122

123 The most widespread Bostrychia species throughout the Southern Hemisphere is $B$.

124 intricata (Bory de Saint-Vincent) Montagne (King and Puttock 1989, Zuccarello and

125 West 2008). This species is normally found in clumps in the upper intertidal either on

126 shaded rocks (King \& Puttock 1989) or logs (Fraser et al. 2013). Phylogenetic

127 research using plastid-encoded Rubisco spacer sequences of $B$. intricata has indicated

128 high levels of genetic diversity within this species, suggesting the presence of

129 multiple cryptic species (Zuccarello and West 2008). More recent research on the 
130 evolution of Bostrychia species endemic to the Southern Hemisphere based on

131 phylogenetic analyses and species delimitation methods using three different

132 molecular markers indicated that eight cryptic species (N1-N8) should be recognized

133 within B. intricata, three of which (N2, N4 and N5) occur in NZ (Muangmai et al.

134 2014). Additionally, a preliminary study on the phylogeography of $B$. intricata from

135 the high latitudes of the Southern Hemisphere (New Zealand, southern South America

136 and some sub-Antarctic islands) indicated strong phylogeographic structure within

137 this species, although some lineages showed evidence of recent long-distance, trans-

138 oceanic dispersal (Fraser et al. 2013).

140 Despite the broad-scale studies of phylogenetic diversity and phylogeography of $B$.

141 intricata in the Southern Hemisphere, our knowledge of how far these cryptic species

142 differ in aspects of their genetic diversity, connectivity and history are still limited. By

143 investigating the phylogeography and population structure of cryptic $B$. intricata

144 species in NZ based on partial COI sequences, we test the hypotheses that (i) different

145 cryptic species showed significant differences in genetic diversity and demographical

146 history, and (ii) the observed differences in phylogeographic patterns of these cryptic

147 species were associated with the historical events and changing environments.

149 MATERIALS AND METHODS

150 Algal sampling

151 Specimens of the morphospecies B. intricata were collected along the coasts of the 152 North and South Islands of NZ in 2011-2012. Details of locations and sample sizes 153 for 43 populations (NZ1-NZ43) are listed in Table 1. This morphospecies normally 154 formed patches on shaded rocks in the upper intertidal. To avoid collecting the same 
155 individual, algal samples were randomly collected from patches which were at least

$1560.5 \mathrm{~m}$ apart. Algal specimens were preserved with silica gel in the field. All

157 specimens were identified based on previous species descriptions (e.g. King and

158 Puttock 1989, Zuccarello and West 2008). For DNA analyses, algal samples were

159 rinsed with autoclaved seawater to remove any sand and dirt, and then the apical

160 portions were used for DNA isolation.

161

162 DNA Extraction, PCR and Sequencing

163 DNA was extracted using a modified Chelex method (Zuccarello et al. 1999a). We

164 chose the short fragment of cytochrome c oxidase subunit I (COI, mitochondrial

165 DNA) as an appropriate molecular marker for this population study because it showed

166 the greatest level of genetic variation in discriminating cryptic species within $B$.

167 intricata when compared to other makers (Muangmai et al. 2014). PCR amplification

168 and sequencing of COI was performed using two sets of primer: GazF1 and GazR2

169 (Saunders 2005) or BstCF2 and BstCR2 (Fraser et al. 2013). The PCR reaction profile

170 followed Saunders (2005) or Fraser et al. (2013). PCR amplification was checked by

171 electrophoresis on a $1 \%$ agarose gel, and PCR products were subsequently purified

172 using ExoSAP-IT (USB, Cleveland, OH, USA). Purified PCR products were

173 sequenced commercially (Macrogen Inc., Seoul, Korea).

174

175 Alignment of DNA sequence and data analyses

176 All DNA sequences were edited and aligned using Geneious 6.0 software

177 (Biomatters, http://www.geneious.com) and then manually checked. For phylogenetic

178 analyses, the data set included haplotypes obtained from this study and additional

179 sequences retrieved from GenBank (Table S1). Phylogenetic relationships were 
180 determined using Maximum Likelihood (ML) and Bayesian Inference (BI), and two

181 sequences of $B$. arbuscula and B. gracilis were used as outgroups following

182 Muangmai et al. (2014). DNA substitution models were determined using Kakusan 4

183 (Tanabe 2011). ML analyses were performed in raxmlGUI v1.3 (Silvestro and

184 Michalak 2012) with the GTR + I + R under the option 'ML + thorough bootstrap',

185 and bootstrapping values were calculated from 1,000 pseudoreplicates. BI analyses

186 were conducted with MrBayes v3.2 (Ronquist et al. 2012) under the best model

187 indicated by BIC (K80 + G to the codon position 1 and HKY85 $+\mathrm{G}$ to the codon

188 position 2 and 3). Two runs of Markov Chain Monte Carlo (MCMC) were performed

189 for 2,000,000 generations, sampling every 100 generations, and the first $25 \%$ of saved

190 trees were discarded as burn-in. ML and BI trees were edited with the program

191 FigTree v1.3.1 (Rambaut 2009).

192

193 Haplotype analysis was performed using the data set that included all sequences

194 generated in this study and haplotypes from Fraser et al. (2013). The genetic diversity

195 indices, including number of haplotypes $(H)$, number of segregating sites $(S)$,

196 haplotype diversity $(H d)$ and nucleotide diversity $(\pi)$, for each population were

197 assessed using DnaSP v5.10.01 (Librado and Rozas 2009). Statistical parsimony

198 networks were constructed using TCS 1.21 (Clement et al. 2000) to observe the

199 relationships among haplotypes.

200

201 Cryptic species were defined based on phylogenetic and species delimitation methods

202 (Muangmai et al. 2014), and population structure and demographic history were

203 separately analyzed for each major lineage. For population genetic analysis,

204 populations with a sample size of eight individuals or more were selected (Felsenstein 
205 2006), and two populations from a previous study (Fraser et al. 2013) were included

206 (here coded as populations NZ44 from Brighton, South Island, and NZ46 from

207 Stewart Island: see Table S1). Pairwise fixation index $\left(F_{\mathrm{ST}}\right)$ values between

208 populations were calculated using Arlequin v 3.5.1.3 (Excoffier and Lischer 2010).

209 The significance of $F_{\mathrm{ST}}$ values was estimated by 1023 random permutations

210 (Schneider et al. 2000). Population structure was further analyzed using the

211 SAMOVA algorithm (Dupanloup et al. 2002) to define groups of populations based

212 on the combined information between geographic distances and genetic variation,

213 implemented in SPADS 1.0 (Dellicour and Mardulyn 2014). The criteria for

214 SAMOVA analysis were set as the number of groups $(\mathrm{K})$ ranging from 2 to 10 , and

21510,000 runs of iterations with 10 repetitions. The optimal number of $\mathrm{K}$ was

216 considered based on a maximum or plateau of $F_{\text {Cт }}$ value. Furthermore, populations

217 were partitioned into the biogeographic regions described by Apte and Gardner

218 (2002) and Shears et al. (2008), as eastern north, western north, eastern south and

219 western south regions (Fig. S1), and population differentiation among these four

220 regions was subsequently tested using the hierarchical analysis of molecular variance

221 (AMOVA) in Arlequin, with significance determined by 10,000 permutations.

223 Historic population demography was determined using three different methods:

224 statistical tests of neutrality, mismatch distribution and the estimation of time to the

225 most recent common ancestor. Tajima's $D$ (Tajima 1989) and Fu's $F_{\mathrm{S}}$ tests were used

226 to test for deviation from selective neutrality, and these analyses were carried out

227 using DnaSP. Analyses of mismatch distribution were performed in Arlequin with

2281000 bootstrap replicates. This method can indicate past population expansion by

229 mode shape: unimodal for a recent population expansion and multimodal for a 
230 stationary population at demographic equilibrium (Harpending 1994). The time to

231 most recent common ancestor (TMRCA) was performed using BEAST v2.0.2

232 (Drummond et al 2012). Mutation rates for COI were estimated following Muangmai

233 et al (2014) with $0.13-0.15$ substitutions per site per million years. Data were

234 partitioned by codon, and substitution models were set as for the phylogenetic

235 analyses. The MCMC analyses were achieved with four independent runs for 20

236 million generation under the assumptions of an uncorrelated lognormal relaxed clock

237 and a Yule model prior. The initial $25 \%$ of saved trees were removed as the burn-in,

238 and a maximum credibility tree based on the remainder was produced using

239 TreeAnnotator v2.0.2 (part of the BEAST v2.0.2 package). The time-calibrated tree

240 with 95\% highest posterior density was visualized in FigTree.

242 RESULTS

243 Genetic diversity and distribution

244 Partial COI sequences of 376 bps were successfully obtained from 384 samples of 43

245 populations of B. intricata around NZ (Fig. 1, Table 1). Genetic distance among these

246 sequences ranged from $0.2 \%$ to $12.8 \%$. Phylogenetic trees obtained from ML and BI

247 analyses were almost completely topologically congruent, and supported the

248 hypothesis that three different cryptic species of $B$. intricata: N2, N4 and N5, referred

249 to in Muangmai et al. (2014) occur in NZ (Fig. S2). Of the 384 samples, most of the

250 samples (250) were from species N4, while another 128 and six samples belonged to

251 species N2 and N5 respectively. A total of 31 different haplotypes were identified (10

252 for N2, 20 for N4 and 2 for N5) (Fig. 2, Table 1). Haplotype and genetic diversity

253 indices of the three cryptic species in each population are presented in Table 1.

254 Haplotype diversity $(H d)$ ranged from 0.35 to 0.68 for species N2 and from 0.20 to 
2550.83 for species N4 (Table 1 ). Nucleotide diversity $(\pi)$ was relatively low for all

256 species, varying from 0.0009 to 0.0042 for species N2, and from 0.0005 to 0.0139 for

257 species N4 (Table 1).

258

259 The most widely distributed cryptic species of $B$. intricata in NZ was N4, which was 260 recorded in 37 populations (Fig. 1). In contrast, species N2 and N5 were restricted to 261 the North Island and top of the South Island (Fig. 1). Species N2 was detected in 19 262 populations, whereas species N5 was rare and only found in three populations (NZ16, 263 NZ19 and NZ27) around Cook Strait, the strait between the North and South Islands.

264 Although two different species were found to coexist at quite a few (12) sites, only 265 one site (Moa Point population: NZ12) had all three species occurring in sympatry 266 (Fig. 1).

267

268 Haplotype networks constructed for the partial COI dataset (including NZ haplotypes 269 from Fraser et al. 2013) are presented in Fig. 2. Species N2 consisted of 11 haplotypes 270 (1-4 bp differences), and its haplotype network was star-like with a central, common $271(71 \%)$ haplotype, 2A, occurring across nearly all populations where this species was 272 found (Fig. 2). Haplotypes $2 \mathrm{~K}$ and $2 \mathrm{G}$ were only detected from populations on the 273 east coast of the North Island, while haplotype 2I was shared among populations from 274 the top of the South Island (Fig. 1, Table 1). The seven other haplotypes were found 275 only in single populations (Table 1). Cryptic species N4 showed the highest diversity, 276 comprising 28 haplotypes (1-16 bp difference) with complex relationships (Fig. 2).

277 Several common haplotypes were detected, for example 4E1, 4A and 4V. 4E1 was the 278 most abundant haplotype, which occurred in 22 of 46 populations around NZ, 279 accounting for $44 \%$ of the samples for this species. The haplotype $4 \mathrm{~A}$ was commonly 
280 found in populations on the east coast of the South Island (14\%), while haplotype 4V

281 was shared across populations around the west coast of the South Island (8\%)(Fig.1

282 and Table 1). Another eight haplotypes of N4 were observed in at least two

283 populations, whereas the remaining 17 haplotypes were only found in single

284 populations (Fig. 1, Table1). Cryptic species N5 had low diversity, containing only

285 two different haplotypes, 5A and 5B, (2 bp differences), although far fewer samples

286 of this species were found than for the other two species. Haplotype 5A was found in

287 populations from the southern North Island (NZ12 and NZ16), while 5B was only

288 found in one population, NZ27, from the top of South Island (Fig. 1, Table 1).

Population structure

291 Population differentiation was separately analyzed for cryptic species N2 (9

292 populations) and N4 (21 populations). Population pairwise $F_{\mathrm{ST}}$ values indicated the

293 significant genetic differentiation among some populations of cryptic species N2

294 (Table S2). The $F_{\mathrm{ST}}$ analyses also showed that the genetic differentiations among the 295 geographically distant populations were relatively low or not significant (Table S2).

296 For example, the Titirangi Bay population (NZ 26) from the top of the South Island

297 was weakly, but significantly genetic differentiated from populations at the bottom of 298 the North Island (Red rock (NZ18) and Moa Point (NZ12)), less than 80 kilometers 299 away, but not significantly different from more distant populations from the upper 300 eastern North Island (Maraetai Bay (NZ5) and Waihau Bay (NZ6), more than 1000 301 kilometers away) (Table S2). In contrast, species N4 showed highly significant 302 population differentiation among some areas (Table S3). Genetic differentiation 303 between proximate populations was also observed on the west coast of the South 304 Island. For example, the Gentle Annie population (NZ40) was significantly 
305 differentiated from the nearby population (less than $40 \mathrm{~km}$ away) of Gibson's Beach

306 (NZ41) as well as the more distant population (more than $900 \mathrm{~km}$ away) of Waipatiki

307 Beach (NZ8) (Table S3).

308

309 Population structure analyses based on the SAMOVA algorithm showed that 9

310 populations of cryptic species N2 were clustered into two groups: Castle Point

311 population (group 1; NZ10) and eastern North Island and top of South Island (group

312 2; NZ5, NZ6, NZ7, NZ9, NZ11, NZ12, NZ18 and NZ26) (maximum $F_{\mathrm{CT}}=0.336, P<$

3130.05 at $\mathrm{K}=2$ ), whereas 21 populations of cryptic species N4 were assigned to six

314 differentiated groups $\left(F_{\mathrm{CT}}=0.824, P<0.05\right.$ at $\left.\mathrm{K}=6\right)$ (Fig. 3). The six groups of

315 cryptic species N4 proposed by SAMOVA were: west coast of North Island and top

316 of South Island (group 1; NZ3, NZ13, NZ17, NZ30, NZ32, NZ33, NZ34, NZ36 and

317 NZ37), east coast of North Island (group 2: NZ8), east coast of South Island (group 3:

318 NZ21, and group 4: NZ 23, NZ24, NZ44 and NZ46) and west coast of South Island

319 (group 5; NZ41, NZ42 and NZ43 and group 6; NZ38 and NZ 39) (Fig. 3).

320 Furthermore, AMOVA analysis of species N4 using the grouping scheme based on

321 four major biogeographic regions proposed by Apte and Gardner (2002) and Shears et

322 al. (2008) (Fig. S1) indicated that $67.57 \%$ of the genetic variation occurred among

323 groups of western and eastern North Island and western and eastern South Island $\left(F_{\mathrm{CT}}\right.$

$324=0.621, P<0.01)$, while lower levels of genetic variation $(14.83 \%)$ existed among

325 populations within groups $\left(F_{\mathrm{SC}}=0.542, P<0.01\right)$ (Table S4).

327 Demographic history and dating analyses

328 The Tajima's D and Fu neutrality tests were used to observe historical population

329 expansions for all populations of cryptic species N2 and N4 of B. intricata. 
330 Significantly negative values of both Tajima's $\mathrm{D}$ and Fu tests $(D=-1.38, P<0.05$;

$\left.331 F_{S}=-3.78, P<0.05\right)$ were observed for species $\mathrm{N} 2$, indicating a recent population

332 expansion. By contrast, the Tajima's D and Fu tests were non-significant $(D=0.55, P$

$\left.333<0.05 ; F_{S}=1.26, P=0.41\right)$ for species $\mathrm{N} 4$, indicating demographically stable

334 populations for this species. Similarly, the mismatch distribution for species N2 was

335 unimodal, supporting a hypothesis of expanding populations, whereas cryptic species

336 N4 showed a multimodal distribution, suggesting more stable populations (Fig. S3).

337 Different patterns of historic population demography in these two cryptic species of $B$.

338 intricata were further supported by the TMRCA analyses. Diversified among species

339 was inferred to have occurred in the late Pleistocene $(<0.2$ million years ago) (Fig.

340 S4). The diversification of cryptic species N2 appears to have occurred between

$34155,000-12,000$ years ago, while the diversification of cryptic species N4 occurred

342 earlier, around 190,000 - 80,000 years ago (Fig S4). Cryptic species N5 seemed to be

343 recently evolved, around 20,000 - 2,000 years ago (Fig. S4).

\section{DISCUSSION}

346 Our molecular analyses indicated different levels of genetic variation and distribution 347 patterns among the three cryptic species of B. intricata in New Zealand, suggesting 348 that each has experienced a different demographic history. Our broad-scale analyses, 349 with samples from 43 sites around the country, strongly support the occurrence of 350 three cryptic species within B. intricata in NZ, as previously indicated by Muangmai 351 et al. (2014); although this earlier study used far fewer samples from NZ. The 352 differences in sample size could occasionally yield the same number of cryptic 353 species; however the large samples are still necessary to precisely assess the genetic 354 diversity and phylogeographic pattern of algal cryptic species (Zuccarello et al. 2006, 
355 Zuccarello et al. 2011). Cryptic species have been detected in other Bostrychia

356 species (Zuccarello and West 2003, 2006, Muangmai et al. 2014) and in other red

357 algal genera (e.g., Porteria hornemannii, Payo et al. 2013 and Spyridia filamentosa,

358 Zuccarello et al. 2002). Previous phylogeographic studies of algae in NZ have

359 indicated genetic differences between northern and southern regions. High levels of

360 genetic variation were found in North Island populations of the brown macroalgae $C$.

361 maschalocarpum and D. antarctica, whereas relatively low genetic variation was

362 encountered in the South Island for C. maschalocarpum, D. antarctica and M.

363 pyrifera (Fraser et al. 2009, Macaya and Zuccarello 2010a, Buchanan and Zuccarello

364 2012). In rough accordance with these findings, we detected three cryptic species (N2,

365 N4 and N5) in northern New Zealand, whereas only one cryptic species (N4) was

366 found in southern New Zealand (Fig. 2). Nonetheless, considerable genetic diversity

367 was detected within and among populations of species N4 in southern New Zealand.

368 High levels of genetic heterogeneity have previously been observed in a brown alga,

369 Adenocystis utricularis (Bory) Skottsberg, from the eastern coast of the South Island

370 (Fraser et al. 2013), and it has been proposed that both A. utricularis and B. intricata

371 may be less susceptible to population decline during glacial periods than the larger

372 kelps (Fraser et al. 2013).

373

374 Distributions of cryptic species N2 and N5 was mostly confined in North Island and

375 top of the South Island, as this pattern detected by the samples of their populations

376 being restricted north of Cape Campbell (east coast) and Golden Bay (west coast) of

377 the South Island (Fig. S1). Many phylogeographic studies of marine taxa in NZ have

378 previously demonstrated that the contemporary upwelling or ocean currents around

379 Cape Campbell and Golden Bay form a significant biogeographic barrier between the 
380

381

382

383

384

403 Another non-mutually exclusive possibility is that these cryptic species have

404 responded differently to historical events and regional climate change, and this

northern and southern biogeographic province (Fig. S1), this was found, for example, in greenshell mussel (Apte and Gardner 2002), seastars (Spocer and Roy 2002, Ayers and Waters 2005) and limpets (Goldstien et al. 2006). It is possible that the restricted northern distribution observed in B. intricata species N2 and N5 is due to this northsouth biogeographic break and the inability of these species to establish past this barrier. However, previous population studies of NZ seaweed showed no evidence for this north-south split, for example, the brown alga Carpophyllum maschalocarpum exhibited a population disjunction in the middle of the North Island (Buchanan and Zuccarello 2012). The observed incongruent pattern of species distribution may be attributable to the differences in life history, dispersal and adaptive capacity of the various cryptic species

Present-day patterns of high levels of genetic diversity can indicate population stability (Grant and Bowen 1998). The differences in genetic diversity and distributions between cryptic $B$. intricata species may be that the three species originated and evolved at different times in the past. Our dating analyses indicated that species N4 is older than either species N2 or N5. If cryptic species N4 arose early, it would have had more time to accumulate mutations than the other cryptic species, and would have had a longer time to adapt to conditions around NZ. It may also have benefited from a relative absence of competition; assuming that all three cryptic species share similar habitat requirements, the later-evolving lineages will have had to compete with existing populations of species N4 for resources. 
405 promoted the disparity in genetic composition and distribution patterns between them.

406 The LGM is a well-known historic event that played an important role in shaping

407 population diversity and connectivity of marine taxa in the Southern Hemisphere

408 (Fraser et al. 2012), and its main impacts were approximately 27,000 - 18,000 years

409 ago (Suggate and Almond 2005). Some studies indicated that the LGM had a

410 significant impact on the genetic diversity and structure of algal species. For example,

411 the observed genetic homogeneity of some brown seaweeds (Carpophyllum

412 maschalocarpum and Durvillea antarctica) from low latitude populations (South

413 Island of New Zealand and sub-Antarctic Island) suggest that these algae may have be

414 removed by ice scouring during the LGM or changes in water temperature and then

415 recolonized in the post-glaciation period (Fraser et al. 2009, Buchanan and Zuccarello

416 2012). The LGM is likely to have facilitated the patterns of genetic diversity and

417 distribution within cryptic $B$. intricata species. Of the three different cryptic $B$.

418 intricata species, we found that the origin of species N4 (180,000 - 90,000 years ago)

419 predated the LGM, and this cryptic species seemed to have survived the glaciation

420 period while retaining its genetic diversity, as indicated by the high-level genetic

421 diversity and wide distribution in both North and South Islands. On the other hand,

422 the diversifications of cryptic species N2 (55,000-12,000 years ago) and N5 (20,000

$423-2,000$ years ago) could have existed during the LGM or have post-dated the LGM.

424 The low genetic diversity and more limited distribution observed in cryptic species

425 N2 and N5 could be explained by two possibilities. Firstly, cryptic species N2 and N5

426 were eliminated from southern areas, and populations in the north contracted, and

427 later were prevented from moving southward after the LGM; secondly these two

428 species diversified after the LGM and then expanded their populations but were

429 prevented from dispersing past the north-south barrier. Both scenarios suggest the 
430 influences of a climate change after glaciation (e.g. warmer seawater in northern New

431 Zealand or rising seawater level at the Cook Strait) on their diversifications and

432 distribution. From these observed patterns, we also hypothesize that the three cryptic

433 species may have different genetic-physiological adaptations and abilities to persistent

434 in changing environments. Further studies on whether these cryptic $B$. intricata

435 species are different in eco-physiological responses (e.g. temperature, exposure),

436 would help to shed light on the mechanism facilitating the genetic differentiation and

437 distribution pattern in the genus Bostrychia or even in other marine red algae.

438

439 Phylogeographic research on marine macroalgae in the Southern Hemisphere have

440 shown that the pattern of population differentiation and connectivity have relied on

441 dispersal potential (Fraser et al. 2009, Macaya and Zuccarello 2010a), habitat

442 availability and density (Montecinos et al. 2012) and the effect of historical events

443 and environmental changes (Fraser et al. 2009, Macaya and Zuccarello 2010b,

444 Buchanan and Zuccarello 2012). For examples, kelp species (e.g. Durvillea antarctica

445 and Macrocystis pyrifera), with high dispersal potential, have demonstrated a higher

446 level of population connectivity than other marine algae with low effective dispersal

447 potential (e.g. Mazzaella laminarioides) (Fraser et al. 2009, Macaya and Zuccarello

448 2010b, Montecinos et al. 2012). In B. intricata, we detected disparate patterns of

449 population structure between two cryptic species, suggesting higher level of gene

450 flow in cryptic species N2 than N4, and this pattern is likely be related to their

451 differences in the extent of dispersal frequency. Our results in population and dating

452 analyses, which indicate that cryptic species N2 has expanded more recently than

453 species N4, may also explain the different patterns observed in cryptic species N2 and

454 N4. We suggest that the difference in evolutionary and demographic history of 
455 species could be another possibility to account for the differences in population

456 structure and connectivity of cryptic algal species.

457

458 Our SAMOVA results support the major biogeographic provinces previously

459 proposed for NZ, with northern/southern biogeographic provinces (B. intricata N4

460 groupings 1, 2, 6 versus 3, 4, 5) (Apte and Gardner 2002, Sharyn et al. 2006) and a

461 genetic split between western/eastern regions, especially on the South Island ( $B$.

462 intricata N4 groupings 5,6 versus 3, 4) (Jones et al. 2008, Veale \& Lavery 2012) (Fig.

463 3). However, SAMOVA analyses for cryptic species N2 and N4 suggested that these

464 groupings were partially incongruent with the 11 bioregions as proposed by Shears et

465 al. (2008), with some groupings spanning several of the proposed regions, especially

466 on the North Island. For example, we found evidence for connectivity between the

467 northeastern and the Portland regions on the North Island for cryptic species N2

468 (group 1, Fig. 3) and the Raglan region and the Abel region on the North Island for

469 cryptic species N4 (group 1, Fig. 3). Our mitochondrial data may not, however, have

470 been able to detect all biogeographic detail; more rapidly-evolving markers (such as

471 microsatellites) could be used in future studies to assess whether fine-scale structure

472 or population connectivity occurs in these regions.

473

474 In conclusion, our data clearly show the occurrence of three cryptic species of $B$.

475 intricata (N2, N4 and N5) in NZ. We have not been able to find any morphological

476 difference between these species. This is very common in Bostrychia species that do

477 not have many morphological characters to investigate (Zuccarello and West 2003).

478 These cryptic species substantially differ in the level of genetic diversity, distribution

479 pattern and demographic histories. While a single marker may not provide all the 
480 evidence of a species history, variable organellar markers do give one level of

481 understanding of a species history, and are commonly used when nuclear markers

482 have not been developed. These findings highlight that different pattern of species

483 history can be quite substantial in species that are morphologically indistinguishable

484 (cryptic species). Future research should be carried out on physiological analyses to

485 assess whether these species differ at a non-morpholigcal levels.

486

487 ACKNOWLEDGMENTS

488 For help with collections, we thank: Wendy Nelson, Mike Wilcox, Christian

489 Boedeker and Maren Preuss. We also thank John West for useful discussion and Joe

490 Buchanan for molecular analyses help. Special thanks the Victoria University of

491 Wellington for providing a scholarship to NM.

492 
493

494 Allcock, A. L. \& Strugnell J. M. 2012. Southern Ocean diversity: new paradigms

\section{REFERENCES} from molecular ecology. Trends Ecol. Evol. 27:520-8.

496

497

498

499

500

501

502

503

504

505

506

507

508

509

510

511

512

513

514

515

516

517

Apte, S. \& Gardner, J. P. A. 2002. Population subdivision in the New Zealand greenshell mussel (Perna canaliculus) inferred from single-strand conformation polymorphism analysis of mitochondrial DNA. Mol. Ecol. $11: 1617-35$.

Ayers, K. L. \& Waters, J. M. 2005. Marine biogeographic disjunction in central New Zealand. Mar. Biol. 147:1045-52.

Brante, A., Fernández, M. \& Viard, F. 2012. Phylogeography and biogeography concordance in the marine gastropod Crepipatella dilatata (Calyptraeidae) along the southeastern Pacific coast. J. Hered. 103:630-7.

Buchanan, J. \& Zuccarello, G. C. 2012. Decoupling of short- and long-distance dispersal pathways in the endemic New Zealand seaweed Carpophyllum maschalocarpum (Phaeophyta, Fucales). J. Phycol. 48:518-29.

Clement, M., Posada, D. \& Crandall, K. 2000. TCS: a computer program to estimate gene genealogies. Mol. Ecol. 9: 1657-60.

Collins, C. J., Fraser, C. I., Ashcroft, A. \& Waters, J. M. 2010. Asymmetric dispersal of southern bull $\square$ kelp (Durvillaea antarctica) adults in coastal New Zealand: testing an oceanographic hypothesis. Mol. Ecol. 19:4572-80.

Dellicour, S. \& Mardulyn, P. 2014. SPADS 1.0: a toolbox to perform spatial analyses on DNA sequence data sets. Mol. Ecol. Resour. 14: 647-51.

Drummond, A. J., Suchard, M. A., Xie, D. \& Rambaut, A. 2012. Bayesian phylogenetics with BEAUti and the BEAST 1.7. Mol. Biol. Evol. 29: 1969-73. Dupanloup, I., Schneider, S. \& Excoffier, L. 2002. A simulated annealing approach to 

define the genetic structure of populations. Mol. Ecol. 11:2571-81.

519 Excoffier, L. \& Lischer, H.E. L. 2010. Arlequin suite ver 3.5: A new series of

520

521

522

523

524 525

526

527

528

529

530

532

533

534

535

536 programs to perform population genetics analyses under Linux and Windows. Mol. Ecol. Resour. 10: 564-7.

Felsenstein, J. 2006. Accuracy of coalescent likelihood estimates: Do we need more sites, more sequences, or more loci? Mol. Biol. Evol. 23: 691-700.

Fraser, C. I., Nikula, R., Ruzzante, D. E. \& Waters, J. M. 2012. Poleward bound: biological impacts of Southern Hemisphere glaciation. Trends Ecol. Evol. $27: 462-71$.

Fraser, C. I., Nikula, R., Spencer, H. G., \& Waters, J. M. 2009. Kelp genes reveal effects of subantarctic sea ice during the Last Glacial Maximum. Proc. Natl. Acad. Sci. USA. 106: 3249-53.

Fraser, C. I., Nikula, R. \& Waters, J. M. 2011. Oceanic rafting by a coastal community. Proc. Biol. Sci. 278:649-55.

Fraser, C. I, Zuccarello, G. C., Spencer, H. G., Salvatore, L. C., Garcia, G. R. \& Waters J. M. 2013. Genetic affinities between trans-oceanic of non-buoyant macroalgae in the high latitudes of the Southern Hemisphere. PLOS One 8:e69138.

Grant, W. S. \& Bowen, B. W. 1998. Shallow population histories in deep evolutionary lineages of marine fishes: insights from sardines and anchovies and lessons for conservation. Heredity 89:415-26.

Goldstien, S. J., Schiel, D. R. \& Gemmell N. J. 2006. Comparative phylogeography of coastal limpets across a marine disjunction in New Zealand. Mol. Ecol. $15: 3259-68$.

Harpending, H.C. 1994. Signature of ancient population growth in a low-resolution 
mitochondrial DNA mismatch distribution. Hum. Biol. 66:591-600.

544 Hemmer-Hansen, J., Nielsen, E. E., Gronkjaer, P. \& Loeschcke, V. 2007.

545 Evolutionary mechanisms shaping the genetic population structure of marine

546 fishes; lessons from the European flounder (Platichthys flesus L.). Mol. Ecol.

$547 \quad 16: 3104-18$

548 Hewitt, G. M. 2004. Genetic consequences of climatic oscillations in the Quaternary.

549 Philos. Trans. R. Soc. Lond. B 359:183-95.

550 Jone, T. C., Gemmill C. E. C. \& Pilditch, C. A. 2008. Genetic variability of New

551 Zealand seagrass (Zostera muelleri) assessed at multiple spatial scale. Aqua.

$552 \quad$ Bot. 88: 39-46.

553 King, R. J. \& Puttock, C. F. 1989. Morphology and taxonomy of Bostrychia and

554 Stictosiphonia (Rhodomelaceae / Rhodophyta). Austral. Syst. Bot. 2:1-73.

555 Le Port, A. \& Lavery, S. 2012. Population structure and phylogeography of the short-

556 tailed stingray, Dasyatis brevicaudata (Hutton 1875), in the Southern

557 Hemisphere. J. Hered. 103:174-85.

558 Librado, P. \& Rozas, J. 2009. DnaSP v5: A software for comprehensive analysis

559 of DNA polymorphism data. Bioinformatics 25: 1451-2.

560 Lomolino, M. V., Riddle B. R. \& Brown, J. H. 2006. Biogeography, third edition.

561 Sinauer Association Inc., Sunderland, Massachusetts. 845pp.

562 Macaya, E. C. \& Zucarello, G. C. 2010a. DNA barcoding and genetic divergence in

563 the giant kelp Macrocystis (Laminariales). J. Phycol. 46:736-42.

564 Macaya, E. C. \& Zucarello, G. C. 2010b. Genetic structure of the giant kelp

565 Macrocystis pyrifera along the southeastern Pacific. Mar. Ecol. Prog. Ser.

$566 \quad 420: 103-12$.

567 Montecinos, A., Broitman, B. R., Faugeron, S., Haye, P. A., Tellier, F. \& Guillemin, 
568

569

570

571

572

573

574

575

576

577

578

579

580

581

582

583

584

585

586

587

588

589

590

M. 2012. Species replacement along a linear coastal habitat: phylogeography and speciation in the red alga Mazzaella laminarioides along the south east pacific. BMC Evol. Biol. 12:97.

Muangmai N, West, J. A. \& Zuccarello G. C. 2014. Evolution of four Southern Hemisphere Bostrychia (Rhodomelaceae, Rhodophyta) species: phylogeny,species delimitation and divergence times. Phycologia 53:593$601 .$.

Nikula, R., Fraser, C. I., Spancer, H. G. \& Waters, J. M. 2010. Circumpolar dispersal by rafting in two subantarctic kelp-dwelling crustaceans. Mar. Ecol. Prog. Ser. 405:221-30.

Payo D. A., Leliaert F., Verbruggen H., D’hondt S., Calumpong H. P. \& De Clerck O. 2013. Extensive cryptic species diversity and fine scale-scale endemism in the marine red alga Portieria in the Philippines. P. Roy. Soc. B. - Biol. Sci. 280: 20122660 .

Rambaut, A. 2009. FigTree. v1.3.1. Available at: http://tree.bio.ed.ac.uk/software (last accessed 27 March 2014).

Ronquist, F., Teslenko, M., van der Mark, P., Ayres, D. L., Darling, A., Höhna, S., Larget, B., Liu, L., Suchard, M. A. \& Huelsenbeck, J. P. 2012. MRBAYES 3.2: Efficient Bayesian phylogenetic inference and model selection across a large model space. Syst. Biol. 61: 539-42.

Ross, P. M., Hogg, I. D., Pilditch, C. A. \& Lundquist, C. J. 2009. Phylogeography of New Zealand's coastal benthos. N. Z. J. Mar. Freshw. Res. 43:1009-27.

Ross, P. M., Hogg, I. D., Pilditch, C. A., Lundquist, C. J. \& Wilkins, R. J. 2012. 
591

592

593

594

595

596

597

598

599

600

601

602

603

604

605

606

607

608

609

610

611

612

613

614

615

Population genetic structure of the New Zealand estuarine clam Austrovenus stutchburyi (Bivalvia: Veneridae) reveals population subdivision and partial congruence with biogeographic boundaries. Estuar. Coast. 35:143-54.

Saunders, G. W. 2005. Applying DNA barcoding to red macroalgae: a preliminary appraisal holds promise for future applications. Phil. Trans. R. Soc. B 360: $1879-88$.

Schneider, S., Roessli, D. \& Excoffier, L 2000. Arlequin: a software for population genetic data. Genetics and Biometry Laboratory, University of Geneva, Switzerland.

Sharyn, J. G., Schiel, D. R. \& Gemmell, N. J. 2006. Comparative phylogeography of coastal limpets across a marine disjunction in New Zealand. Mol. Ecol. $15: 3259-68$.

Shears, N. T., Smith, F., Babcock, R. C., Duffy, C. A. \& Villouta, E. 2008. Evaluation of biogeographic classification schemes for conservation planning: application to New Zealand's coastal marine environment. Conserv. Biol. 22:467-81.

Silvestro, D. \& Michalak I. 2012. raxmlGUI: a graphical front-end for RAxML. Org. Divers. Evol. 12: 335-7.

Smith, P. J., McMillan, P. J., Bull, B., McVeagh, S. M., Gaffney, P. M., \& Chow, S. 2002. Genetic and meristic variation in black and smooth oreos in the New Zealand Exclusive Economic Zone. N. Z. J. Mar. Freshw. Res. 36: 737-50.

Spocer, R. \& Roy, M. S. 2002. Phylogeographic analysis of the brooding brittle star Amphipholis squamata (echinodermata) along the coast of New Zealand reveals high cryptic genetic variation and cryptic dispersal potential. Evolution $56: 1954-67$.

Suggate, R. P. \& Almond P. C. 2005. The Last Glacial Maximum (LGM) in western 
616

617

618

620

621

622

623

624

625

626

627

628

630

631

632

633

634

635

636

637

638

639

640

South Island, New Zealand: implications for the global LGM and MIS 2. Quat. Sci. Rev. 24:16-7.

Tajima, F. 1989. Statistical method for testing the neutral mutation hypothesis by DNA polymorphism. Genetics 123: 585-95.

Tanabe, A. S. 2011. Kakusan4 and Aminosan: two programs for comparing nonpartitioned, proportional, and separate models for combined molecular phylogenetic analyses of multilocus sequence data. Mol. Ecol. Resour. $11: 914-21$.

Veale, A. J. \& Lavery S. D. 2012. The population genetic structure of the intertidal waratah anemone (Actinia tenebrosa) around New Zealand. N. Z. J. Mar. Freshw. Res. 46:523-36.

Wallis, G. P. \& Trewick, S. A. 2009. New Zealand phylogeography: evolution on a small continent. Mol. Ecol. 18:3548-80.

Water, J. M. \& Roy, M. S. 2003. Marine biogeography of southern Australia: phylogeographical structure in a temperate sea-star. J. Biogeor. 30:1787-96.

Waters, J. M., Fraser, C. I. \& Hewitt G. M. 2013. Founder takes all: densitydependent processes structure biodiversity. Trends Ecol. Evol. 28:78-85.

Zuccarello, G. C., Buchanan, J. \& West, J. A. 2006. Increased sampling for inferring phylogeographic patterns in Bostrychia radicans/Bostrychia moritziana in the eastern USA. J. Phycol. 42:1349-52.

Zuccarello, G. C., Buchanan, J., West, J. A. \& Pedroche, F. F. 2011. Genetic diversity of the mangrove-associated alga Bostrychia radicans/B. moritziana (Ceramiales, Rhodophyta) from southern Central America. Phycol. Res. 59:98-104.

Zuccarello, G. C., Sandercock, B. \& West, J. A. 2002. Diversity within red algal 
641

642

643

644

645

646

647

648

649

650

651

652

653

654

655

656

657

658

659

660

661

662

663

664 species: variation in world-wide samples of Spyridia filamentosa

(Ceramiaceae) and Murrayella periclados (Rhodomelaceae) using DNA markers and breeding studies. Eur. J. Phycol. 37: 403-18.

Zuccarello, G. C. \& West, J. A. 2003. Multiple cryptic species: molecular diversity and reproductive isolation in the Bostrychia radicans / B. moritziana complex (Rhodomelaceae, Rhodophyta) with focus on North American isolates. $J$. Phycol. 39: 948-59.

Zuccarello, G. C. \& West, J. A. 2006. Molecular phylogeny of the subfamily Bostrychioideae (Ceramiales, Rhodophyta): Subsuming Stictosiphonia and highlighting polyphyly in species of Bostrychia. Phycologia 45:24-36.

Zuccarello, G. C. \& West, J. A. 2008. Bostrychia (Rhodomelaceae, Rhodophyta) species of New Zealand, and relationships in the Southern Hemisphere. N. Z. J. Mar. Freshw. Res. 42:315-24.

Zuccarello, G. C. \& West, J. A. 2011. Insights into evolution and speciation in the red alga Bostrychia: 15 years of research. Algae 26:3-14.

Zuccarello G. C., West J. A., Kamiya M. \& King R. J. 1999a. A rapid method to score plastid haplotypes in red seaweeds and its use in determining parental inheritance of plastid in the red alga Bostrychia (Ceramiales). Hydrobiologia 401: 207-14.

Zuccarello, G. C., West, J. A. \& King, R. J. 1999b. Evolutionary divergence in the Bostrychia moritziana/B. radicans complex (Rhodomelaceae, Rhodophyta): molecular and hybridisation data. Phycologia 38: 234-44. 
Table 1. Sampling sites of cryptic species N2, N4 and N5 of B. intricata in New Zealand and genetic diversity indices. Code= Population code, $N=$ number of samples, $H=$ number of haplotypes, $S=$ number of segregating sites, $H d=$ haplotype diversity, $\pi=$ nucleotide diversity

\begin{tabular}{|c|c|c|c|c|c|c|c|c|}
\hline Code & Sampling site & Coordinates & $N$ & Haplotypes Present & $H$ & $S$ & Hd & $\pi$ \\
\hline \multicolumn{9}{|c|}{ North Island } \\
\hline NZ1 & Casnell Island, Leigh & $\begin{array}{l}36^{\circ} 29^{\prime} 14.21^{\prime \prime S} \\
174^{\circ} 43^{\prime} 37.24^{\prime \prime} \mathrm{E}\end{array}$ & 4 & $\mathrm{~N} 2=2 \mathrm{~A}(4)$ & 1 & 0 & 0.00 & 0.0000 \\
\hline $\mathrm{NZ2}$ & $\begin{array}{l}\text { Sandspit, Snells beach, } \\
\text { Leigh }\end{array}$ & $\begin{array}{l}36^{\circ} 24^{\prime} 13.82^{\prime \prime} \mathrm{S} \\
174^{\circ} 44^{\prime} 09.76^{\prime \prime} \mathrm{E}\end{array}$ & 4 & $\mathrm{~N} 2=2 \mathrm{~A}(4)$ & 1 & 0 & 0.00 & 0.0000 \\
\hline NZ3 & $\begin{array}{l}\text { Waitemata Harbour, } \\
\text { Auckland }\end{array}$ & $\begin{array}{l}36^{\circ} 50^{\prime} 28.93^{\prime \prime} \mathrm{S} \\
174^{\circ} 43^{\prime} 49.74^{\prime \prime} \mathrm{E}\end{array}$ & 10 & $\begin{array}{l}\mathrm{N} 4=4 \mathrm{E} 8(4), 4 \mathrm{E} 9(3), \\
4 \mathrm{E} 10(2), 4 \mathrm{E} 11(1)\end{array}$ & 4 & 7 & 0.77 & 0.0069 \\
\hline NZ4 & $\begin{array}{l}\text { Kaikoura Island, } \\
\text { Huaraki Gulf }\end{array}$ & $\begin{array}{l}36^{\circ} 10^{\prime} 29.40^{\prime \prime} \mathrm{S} \\
175^{\circ} 19^{\prime} 35.56^{\prime \prime} \mathrm{E}\end{array}$ & 1 & $\mathrm{~N} 4=4 \mathrm{E} 8(1)$ & 1 & 0 & 0.00 & 0.0000 \\
\hline NZ5 & $\begin{array}{l}\text { Tekaha, Maraetai Bay, } \\
\text { East Cape }\end{array}$ & $\begin{array}{l}37^{\circ} 43^{\prime} 36.19^{\prime \prime} \mathrm{S} \\
177^{\circ} 41^{\prime} 27.83^{\prime \prime} \mathrm{E}\end{array}$ & 10 & $\mathrm{~N} 2=2 \mathrm{~A}(10)$ & 1 & 0 & 0.00 & 0.0000 \\
\hline
\end{tabular}




\section{$37^{\circ} 31^{\prime} 11.63^{\prime \prime S}$}

NZ6 Waihau Bay, East Cape

$177^{\circ} 55^{\prime} 17.27^{\prime \prime} \mathrm{E}$

$37^{\circ} 32^{\prime} 57.05^{\prime \prime S}$

NZ7 Lottin Point, East Cape

$178^{\circ} 08^{\prime} 03.06^{\prime \prime} \mathrm{E}$

Waipatiki Beach, $\quad 39^{\circ} 18^{\prime} 01.79^{\prime \prime} \mathrm{S}$

NZ8

Hawke Bay

Porangahua beach,

NZ9

Hawke Bay

Castle Point,

NZ10

Wellington

Cape Palliser,

NZ1 1

Wellington

NZ12

$176^{\circ} 58^{\prime} 43.22^{\prime \prime} \mathrm{E}$

$40^{\circ} 18^{\prime} 02.65^{\prime \prime} \mathrm{S}$

$176^{\circ} 40^{\prime} 15.49^{\prime \prime} \mathrm{E}$

$40^{\circ} 54^{\prime} 05.15^{\prime \prime S}$

$176^{\circ} 13^{\prime} 48.61^{\prime \prime} \mathrm{E}$

$41^{\circ} 36^{\prime} 45.48^{\prime \prime} \mathrm{S}$

$175^{\circ} 17^{\prime} 50.83^{\prime \prime} \mathrm{E}$

$41^{\circ} 20^{\prime} 40.78^{\prime \prime S}$
$10 \quad \mathrm{~N} 2=2 \mathrm{~A}(5), 2 \mathrm{D}(2), 2 \mathrm{~K}(3)$

3

2

0.68

0.0021

$10 \quad \mathrm{~N} 2=2 \mathrm{~A}(4), 2 \mathrm{G}(1), 2 \mathrm{~K}(5)$

3

2

0.64

0.0020

$10 \quad \mathrm{~N} 4=4 \mathrm{R}(8), 4 \mathrm{~S}(2)$

17448'35.34"E
$10 \quad \mathrm{~N} 2=2 \mathrm{~A}(8), 2 \mathrm{E}(2)$

$10 \quad \mathrm{~N} 2=2 \mathrm{~F}(4), 2 \mathrm{G}(6)$

$\mathrm{N} 2=2 \mathrm{~A}(10)$

12

$\mathrm{N} 4=4 \mathrm{E} 1(2)$

$\mathrm{N} 2=2 \mathrm{~A}(14)$

$19 \quad \mathrm{~N} 4=4 \mathrm{E} 1(3)$

$\mathrm{N} 5=5 \mathrm{~A}(2)$
1

0.36

0.0009

$2 \quad 1$

0.48

0.0012

2

3

0.53

0.0042

$\mathrm{N} 2=1 \quad \mathrm{~N} 2=0 \quad \mathrm{~N} 2=0.00 \quad \mathrm{~N} 2=0.0000$

$\mathrm{N} 4=1 \quad \mathrm{~N} 4=0 \quad \mathrm{~N} 4=0.00 \quad \mathrm{~N} 4=0.0000$

$\mathrm{N} 2=1 \quad \mathrm{~N} 2=0 \quad \mathrm{~N} 2=0.00 \quad \mathrm{~N} 2=0.0000$

$\mathrm{N} 4=1 \quad \mathrm{~N} 4=0 \quad \mathrm{~N} 4=0.00 \quad \mathrm{~N} 4=0.0000$

$\mathrm{N} 5=1 \quad \mathrm{~N} 5=0 \quad \mathrm{~N} 5=0.00 \quad \mathrm{~N} 5=0.0000$ 


\begin{tabular}{|c|c|c|c|c|c|c|c|c|}
\hline NZ13 & $\begin{array}{l}\text { Manukau Harbour, } \\
\text { Auckland }\end{array}$ & $\begin{array}{l}36^{\circ} 55^{\prime} 52.43^{\prime \prime} \mathrm{S} \\
174^{\circ} 45^{\prime} 18.74^{\prime \prime} \mathrm{E}\end{array}$ & 11 & $\mathrm{~N} 4=4 \mathrm{E} 1(7), 4 \mathrm{E} 7(3), 4 \mathrm{E} 8(1)$ & 3 & 2 & 0.61 & 0.0016 \\
\hline \multirow[t]{2}{*}{ NZ14 } & New Plymount, & $39^{\circ} 03^{\prime} 21.67^{\prime \prime} \mathrm{S}$ & \multirow[t]{2}{*}{6} & $\mathrm{~N} 2=2 \mathrm{~A}(3)$ & $\mathrm{N} 2=1$ & $\mathrm{~N} 2=0$ & $\mathrm{~N} 2=0.00$ & $\mathrm{~N} 2=0.0000$ \\
\hline & Taranaki & $174^{\circ} 03^{\prime} 35.31^{\prime \prime} \mathrm{E}$ & & $\mathrm{N} 4=4 \mathrm{E} 1(3)$ & $\mathrm{N} 4=1$ & $\mathrm{~N} 4=0$ & $\mathrm{~N} 4=0.00$ & $\mathrm{~N} 4=0.0000$ \\
\hline \multirow{2}{*}{ NZ15 } & \multirow{2}{*}{ Cape Egmont, Taranaki } & $39^{\circ} 16^{\prime} 26.79^{\prime \prime} \mathrm{S}$ & \multirow[b]{2}{*}{8} & $\mathrm{~N} 2=2 \mathrm{~A}(1)$ & $\mathrm{N} 2=1$ & $\mathrm{~N} 2=0$ & $\mathrm{~N} 2=0.00$ & $\mathrm{~N} 2=0.0000$ \\
\hline & & $173^{\circ} 45^{\prime} 09.52^{\prime \prime} \mathrm{E}$ & & $\mathrm{N} 4=4 \mathrm{E} 1(4), 4 \mathrm{E} 5(2), 4 \mathrm{E} 6(1)$ & $\mathrm{N} 4=3$ & $\mathrm{~N} 4=2$ & $\mathrm{~N} 4=0.66$ & $\mathrm{~N} 4=0.0023$ \\
\hline \multirow{2}{*}{ NZ16 } & \multirow{2}{*}{ Kapita Coast } & $41^{\circ} 01 ' 21.19^{\prime \prime S}$ & \multirow{2}{*}{6} & $\mathrm{~N} 2=2 \mathrm{~A}(4)$ & $\mathrm{N} 2=1$ & $\mathrm{~N} 2=0$ & $\mathrm{~N} 2=0.00$ & $\mathrm{~N} 2=0.0000$ \\
\hline & & $174^{\circ} 54^{\prime} 26.21^{\prime \prime E}$ & & $\mathrm{~N} 5=5 \mathrm{~A}(2)$ & $\mathrm{N} 5=1$ & $\mathrm{~N} 5=0$ & $\mathrm{~N} 5=0.00$ & $\mathrm{~N} 5=0.0000$ \\
\hline NZ17 & Titahi Bay, Porirua & $\begin{array}{l}41^{\circ} 06^{\prime} 20.79^{\prime \prime} \mathrm{S} \\
174^{\circ} 49^{\prime} 24.49^{\prime \prime} \mathrm{E}\end{array}$ & 10 & $\mathrm{~N} 4=2 \mathrm{E} 1(10)$ & 1 & 0 & 0.00 & 0.0000 \\
\hline NZ18 & Red Rock, Wellington & $\begin{array}{l}41^{\circ} 20^{\prime} 56.38^{\prime \prime S} \\
174^{\circ} 44^{\prime} 27.25^{\prime \prime} \mathrm{E}\end{array}$ & 17 & $\mathrm{~N} 2=2 \mathrm{~A}(11), 2 \mathrm{~J}(6)$ & 2 & 1 & 0.48 & 0.0012 \\
\hline
\end{tabular}

South Island

\begin{tabular}{|c|c|c|c|c|c|c|c|}
\hline \multirow{2}{*}{ NZ19 } & \multirow{2}{*}{ Hakahaka Bay, Picton, } & $41^{\circ} 17^{\prime} 58.22^{\prime \prime S}$ & $\mathrm{~N} 2=2 \mathrm{~A}(2)$ & $\mathrm{N} 2=1$ & $\mathrm{~N} 2=0$ & $\mathrm{~N} 2=0.00$ & $\mathrm{~N} 2=0.0000$ \\
\hline & & $174^{\circ} 06^{\prime} 50.76^{\prime \prime} \mathrm{E}$ & $\mathrm{N} 4=4 \mathrm{E} 1(6)$ & $\mathrm{N} 4=1$ & $\mathrm{~N} 4=0$ & $\mathrm{~N} 4=0.00$ & $\mathrm{~N} 4=0.0000$ \\
\hline
\end{tabular}




\begin{tabular}{|c|c|c|c|c|c|c|c|c|}
\hline NZ20 & $\begin{array}{l}\text { Paparoa Point, } \\
\text { Kaikoura }\end{array}$ & $\begin{array}{l}42^{\circ} 14^{\prime} 10.51^{\prime \prime S} \\
173^{\circ} 50^{\prime} 48.81^{\prime \prime} \mathrm{E}\end{array}$ & 4 & $\mathrm{~N} 4=4 \mathrm{Q}(4)$ & 1 & 0 & 0.00 & 0.0000 \\
\hline NZ22 & $\begin{array}{l}\text { Port Levy, Bank } \\
\text { Peninsula }\end{array}$ & $\begin{array}{l}43^{\circ} 38^{\prime} 52.49^{\prime \prime} \mathrm{S} \\
172^{\circ} 49^{\prime} 10.36^{\prime \prime} \mathrm{E}\end{array}$ & 6 & $\mathrm{~N} 4=4 \mathrm{~A}(6)$ & 1 & 0 & 0.00 & 0.0000 \\
\hline NZ23 & $\begin{array}{l}\text { Pigeon Bay, Bank } \\
\text { Peninsula }\end{array}$ & $\begin{array}{l}43^{\circ} 40^{\prime} 34.11^{\prime \prime S} \\
172^{\circ} 53^{\prime} 27.58^{\prime \prime} \mathrm{E}\end{array}$ & 10 & $\mathrm{~N} 4=4 \mathrm{~A}(8), 4 \mathrm{E} 1(2)$ & 2 & 3 & 0.36 & 0.0028 \\
\hline NZ24 & $\begin{array}{l}\text { French Farm Bay, } \\
\text { Akaroa, Bank Peninsula }\end{array}$ & $\begin{array}{l}43^{\circ} 46^{\prime} 21.43^{\prime \prime} \mathrm{S} \\
172^{\circ} 54^{\prime} 50.99^{\prime \prime} \mathrm{E}\end{array}$ & 10 & $\mathrm{~N} 4=4 \mathrm{~A}(5), 4 \mathrm{E} 1(4), 4 \mathrm{P}(1)$ & 3 & 7 & 0.64 & 0.0064 \\
\hline NZ26 & Titirangi Bay, Havelock & $\begin{array}{l}41^{\circ} 01^{\prime} 08.73 " \mathrm{~S} \\
174^{\circ} 07^{\prime} 57.36^{\prime \prime} \mathrm{E}\end{array}$ & 12 & $\begin{array}{l}\mathrm{N} 2=2 \mathrm{~A}(8), 2 \mathrm{C}(2) \\
\mathrm{N} 4=4 \mathrm{E} 1(2)\end{array}$ & $\begin{array}{l}\mathrm{N} 2=2 \\
\mathrm{~N} 4=1\end{array}$ & $\begin{array}{l}\mathrm{N} 2=1 \\
\mathrm{~N} 4=0\end{array}$ & $\begin{array}{l}\mathrm{N} 2=0.35 \\
\mathrm{~N} 4=0\end{array}$ & $\begin{array}{l}\mathrm{N} 2=0.0009 \\
\mathrm{~N} 4=0.0000\end{array}$ \\
\hline NZ27 & Kenupuru Bay, & $41^{\circ} 11^{\prime} 42.31^{\prime \prime S}$ & 5 & $\mathrm{~N} 4=4 \mathrm{E} 1(4)$ & $\mathrm{N} 4=1$ & $\mathrm{~N} 4=0$ & $\mathrm{~N} 4=0.00$ & $\mathrm{~N} 4=0.0000$ \\
\hline
\end{tabular}




\begin{tabular}{|c|c|c|c|c|c|c|c|c|}
\hline & Havelock & $174^{\circ} 04^{\prime} 28.01^{\prime \prime} \mathrm{E}$ & & $\mathrm{N} 5=5 \mathrm{~B}(1)$ & $\mathrm{N} 5=1$ & $\mathrm{~N} 5=0$ & $\mathrm{~N} 5=0.00$ & $\mathrm{~N} 5=0.0000$ \\
\hline NZ28 & $\begin{array}{l}\text { Te Mahia Bay, } \\
\text { Havelock }\end{array}$ & $\begin{array}{l}41^{\circ} 12^{\prime} 57.31^{\prime \prime S} \\
173^{\circ} 58^{\prime} 16.61^{\prime \prime} \mathrm{E}\end{array}$ & 1 & $\mathrm{~N} 4=4 \mathrm{E} 1(1)$ & 1 & 0 & 0.00 & 0.0000 \\
\hline NZ29 & Double Cove, & $41^{\circ} 14^{\prime} 00.40 " \mathrm{~S}$ & 6 & $\mathrm{~N} 2=2 \mathrm{~A}(3)$ & $\mathrm{N} 2=1$ & $\mathrm{~N} 2=0$ & $\mathrm{~N} 2=0.00$ & $\begin{array}{l}\mathrm{N} 2=0.0000 \\
\mathrm{~N} 4=0.0000\end{array}$ \\
\hline NZ30 & Okiwi Bay, & $41^{\circ} 06^{\prime} 08.72^{\prime \prime} \mathrm{S}$ & 11 & $\mathrm{~N} 2=2 \mathrm{I}(1)$ & $\mathrm{N} 2=1$ & $\mathrm{~N} 2=0$ & $\mathrm{~N} 2=0.00$ & $\mathrm{~N} 2=0.0000$ \\
\hline & Marlborough & $173^{\circ} 39^{\prime} 30.96^{\prime \prime E}$ & & $\mathrm{~N} 4=4 \mathrm{E} 1(9), 4 \mathrm{E} 3(1)$ & $\mathrm{N} 4=2$ & $\mathrm{~N} 4=1$ & $\mathrm{~N} 4=0.20$ & $\mathrm{~N} 4=0.0005$ \\
\hline NZ31 & Cable Bay, Nelson & $\begin{array}{l}41^{\circ} 09^{\prime} 18.93 " \mathrm{~S} \\
173^{\circ} 25^{\prime} 03.61^{\prime \prime} \mathrm{E}\end{array}$ & 8 & $\begin{array}{l}\mathrm{N} 2=2 \mathrm{H}(1), 2 \mathrm{I}(1) \\
\mathrm{N} 4=4 \mathrm{E} 1(2), 4 \mathrm{E} 4(1), 4 \mathrm{O}(1)\end{array}$ & $\begin{array}{l}\mathrm{N} 2=2 \\
\mathrm{~N} 4=3\end{array}$ & $\begin{array}{l}\mathrm{N} 2=1 \\
\mathrm{~N} 4=10\end{array}$ & $\begin{array}{l}\mathrm{N} 2=0.66 \\
\mathrm{~N} 4=0.83\end{array}$ & $\begin{array}{l}\mathrm{N} 2=0.0017 \\
\mathrm{~N} 4=0.0139\end{array}$ \\
\hline NZ32 & Burton, Nelson & $\begin{array}{l}41^{\circ} 19^{\prime} 10.52^{\prime \prime} \mathrm{S} \\
173^{\circ} 10^{\prime} 28.72^{\prime \prime} \mathrm{E}\end{array}$ & 13 & $\begin{array}{l}\mathrm{N} 2=2 \mathrm{~A}(1) \\
\mathrm{N} 4=4 \mathrm{E} 1(12)\end{array}$ & $\begin{array}{l}\mathrm{N} 2=1 \\
\mathrm{~N} 4=1\end{array}$ & $\begin{array}{l}\mathrm{N} 2=0 \\
\mathrm{~N} 4=0\end{array}$ & $\begin{array}{l}\mathrm{N} 2=0.00 \\
\mathrm{~N} 4=0.00\end{array}$ & $\begin{array}{l}\mathrm{N} 2=0.0000 \\
\mathrm{~N} 4=0.0000\end{array}$ \\
\hline NZ33 & $\begin{array}{l}\text { Astrolabe, Sandy Bay, } \\
\text { Abel Tasman NP }\end{array}$ & $\begin{array}{l}40^{\circ} 59^{\prime} 46.93^{\prime \prime} \mathrm{S} \\
173^{\circ} 00^{\prime} 40.86^{\prime \prime} \mathrm{E}\end{array}$ & 10 & $\mathrm{~N} 4=4 \mathrm{E} 1(10)$ & 1 & 0 & 0.00 & 0.0000 \\
\hline NZ34 & $\begin{array}{l}\text { Coquille Bay, Abel } \\
\text { Tasman National Park }\end{array}$ & $\begin{array}{l}40^{\circ} 59^{\prime} 21.04^{\prime \prime} \mathrm{S} \\
173^{\circ} 01^{\prime} 49.51^{\prime \prime} \mathrm{E}\end{array}$ & 10 & $\mathrm{~N} 4=4 \mathrm{E} 1(10)$ & 1 & 0 & 0.00 & 0.0000 \\
\hline
\end{tabular}


Tinline Bay, Abel $\quad 40^{\circ} 59^{\prime} 25.25^{\prime \prime} \mathrm{S}$

NZ35

Tasman National Park $\quad 173^{\circ} 01^{\prime} 40.51$ "E
$4 \quad \mathrm{~N} 4=4 \mathrm{E} 1(4)$
1
0
0.00
0.0000

$40^{\circ} 48^{\prime} 13.01 " \mathrm{~S}$

NZ36 Wainui Bay, Tasman

$172^{\circ} 57^{\prime} 11.13^{\prime \prime} \mathrm{E}$

$11 \quad \mathrm{~N} 4=4 \mathrm{E} 1(11)$

1

0

0.00

0.0000

$40^{\circ} 49^{\prime} 47.53^{\prime \prime} \mathrm{S}$

NZ37 Pohara, Tasman

$172^{\circ} 53^{\prime} 32.16^{\prime \prime} \mathrm{E}$

$11 \quad \mathrm{~N} 4=4 \mathrm{E} 1(10), 4 \mathrm{E} 2(1)$

2

1

0.51

0.0013

Wharariki Beach,

$40^{\circ} 30^{\prime} 02.63^{\prime \prime} \mathrm{S}$

NZ38

Puponga

$172^{\circ} 40^{\prime} 52.24 " \mathrm{E}$

$10 \quad \mathrm{~N} 4=4 \mathrm{~T}(7), 4 \mathrm{~V}(2), 4 \mathrm{Y}(1)$

3

2

0.51

0.0018

Whanganui Inlet,

$40^{\circ} 34^{\prime} 52.61 " \mathrm{~S}$

NZ39

Tasman

$172^{\circ} 37^{\prime} 47.46^{\prime \prime} \mathrm{E}$

$12 \quad \mathrm{~N} 4=4 \mathrm{E} 1(7), 4 \mathrm{~V}(5)$

2

9

0.62

0.0132

Gentle Antie Seaside, $\quad 41^{\circ} 30^{\prime} 21.81^{\prime \prime S}$

NZ40

Westport

$171^{\circ} 56^{\prime} 46.86^{\prime \prime} \mathrm{E}$

$10 \quad \mathrm{~N} 4=4 \mathrm{~W}(10)$

1

0

0.00

0.0000

Gibsob's Beach, Cape $\quad 41^{\circ} 44^{\prime} 53.13^{\prime \prime S}$

NZ41

Foulwind, Westport

$171^{\circ} 28^{\prime} 16.06^{\prime \prime} \mathrm{E}$

$10 \quad \mathrm{~N} 4=4 \mathrm{~V}(7), 4 \mathrm{X}(3)$

$2 \quad 1$

0.46

0.0012

NZ42 Tauranga Bay,

$41^{\circ} 46 ' 25.31 " \mathrm{~S}$

$10 \quad \mathrm{~N} 4=4 \mathrm{~T}(4), 4 \mathrm{~V}(6)$

$2 \quad 1$

0.53

0.0014 


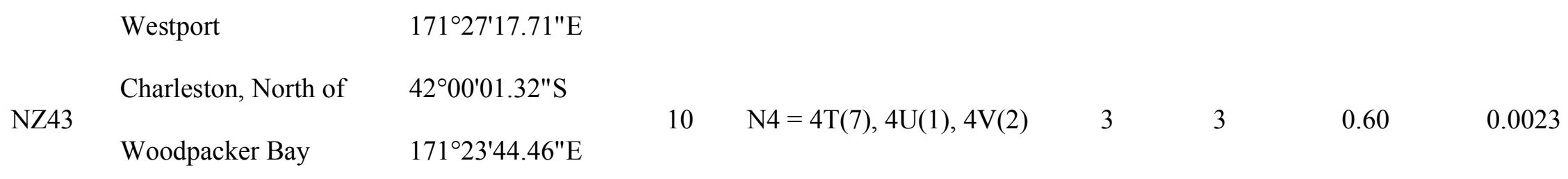

South Island - additional data from Fraser et al. (2013)

\begin{tabular}{|c|c|c|c|c|c|c|c|c|}
\hline NZ44 & Brighton, Dunedin & $\begin{array}{l}45^{\circ} 56 ' 54.91 " \mathrm{~S} \\
170^{\circ} 20^{\prime} 12.72 " \mathrm{E}\end{array}$ & 9 & $\mathrm{~N} 4=4 \mathrm{~A}(8), 4 \mathrm{~N}(1)$ & 2 & 8 & 0.22 & 0.0048 \\
\hline NZ45 & $\begin{array}{l}\text { Stewart Island: } \\
\text { Ringaringa }\end{array}$ & $\begin{array}{l}45^{\circ} 54^{\prime} 09.07^{\prime \prime} \mathrm{S} \\
168^{\circ} 08^{\prime} 41.10^{\prime \prime} \mathrm{E}\end{array}$ & 7 & $\begin{array}{l}\mathrm{N} 4=4 \mathrm{~A}(4), 4 \mathrm{~B}(1), 4 \mathrm{C}(1), \\
4 \mathrm{~F}(1)\end{array}$ & 4 & 3 & 0.64 & 0.0023 \\
\hline NZ46 & $\begin{array}{l}\text { Stewart Island: The } \\
\text { Neck }\end{array}$ & $\begin{array}{l}45^{\circ} 55^{\prime} 25.37^{\prime \prime} \mathrm{S} \\
168^{\circ} 11^{\prime} 26.95^{\prime \prime} \mathrm{E}\end{array}$ & 8 & $\mathrm{~N} 4=4 \mathrm{~A}(6), 4 \mathrm{~B}(1), 4 \mathrm{C}(1)$ & 3 & 2 & 0.52 & 0.0015 \\
\hline
\end{tabular}




\section{Figure Legends}

Fig. 1. Distribution of three cryptic Bostrychia intricata species based on COI data. Each pie chart shows the proportion of cryptic species and their haplotypes. Colors represent different cryptic species: Grey: species N2; Black: species N4; and White: species N5. Population codes and sample sizes are indicated next to the pie charts (see also Table 1).

Fig. 2. COI haplotype networks for cryptic Bostrychia intricata species (N2, N4, N5) obtained from the TCS analyses. Colors represent the different cryptic species as indicated in Fig. 1. Solid circles correspond to haplotypes found in this study, and dashed circles correspond to haplotypes from Fraser et al. (2013). Small circles represent inferred missing or extinct haplotypes.

Fig. 3. Cluster analyses base on SAMOVA algorithm for cryptic Bostrychia intricata species N2 (A) and N4 (B). Small circles represent the populations sampled in this analysis (see Fig 1 and Table 1). Shaded areas show population grouping designated by $\mathrm{K}=2$ for cryptic species $\mathrm{N} 2$ (group 1 and 2) and $\mathrm{K}=6$ for cryptic species N4 (group $1-6)$. Solid black lines show the separation of the northern and southern biogeographic provinces of New Zealand according to Apte and Gardner (2002). 


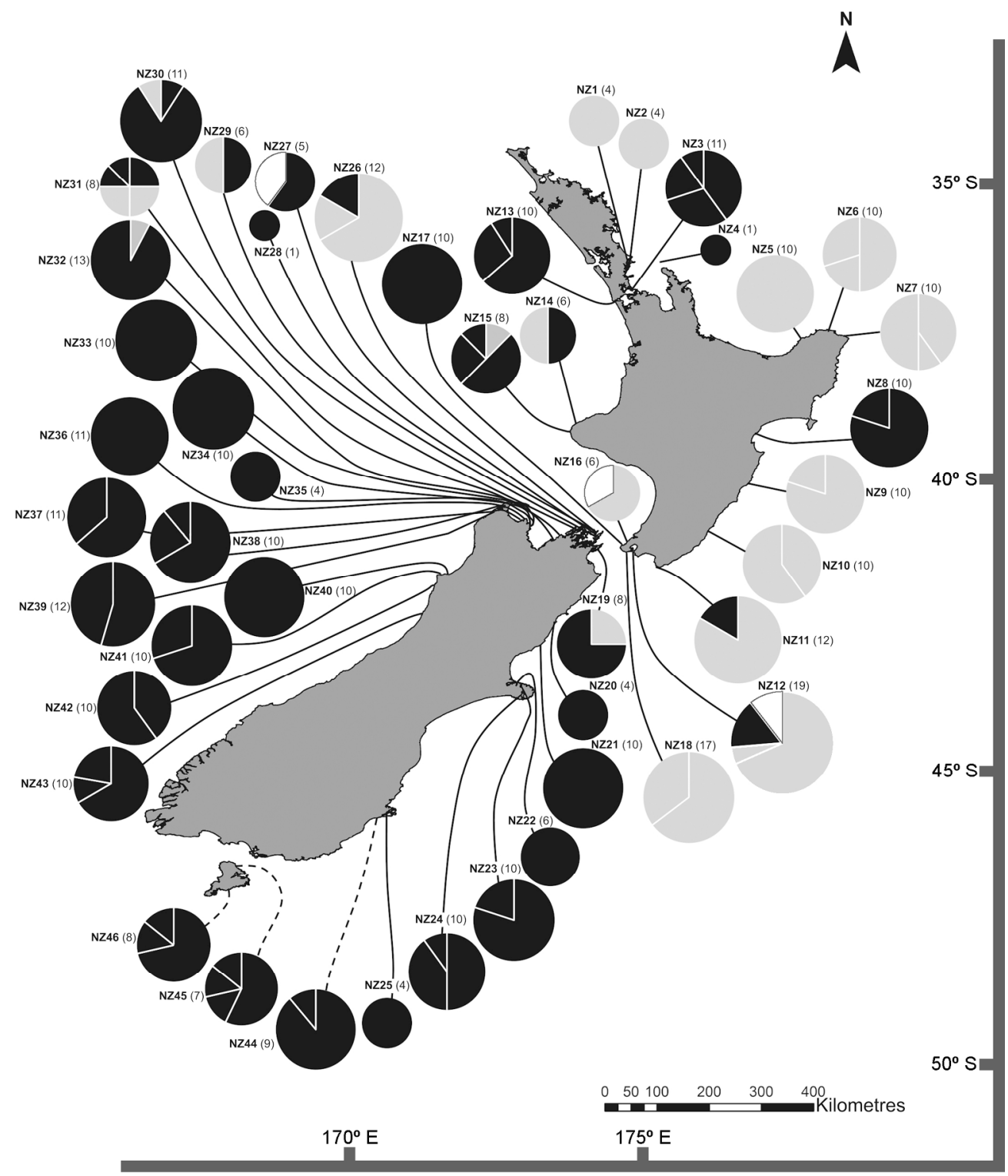

$185 \times 220 \mathrm{~mm}(300 \times 300$ DPI $)$ 


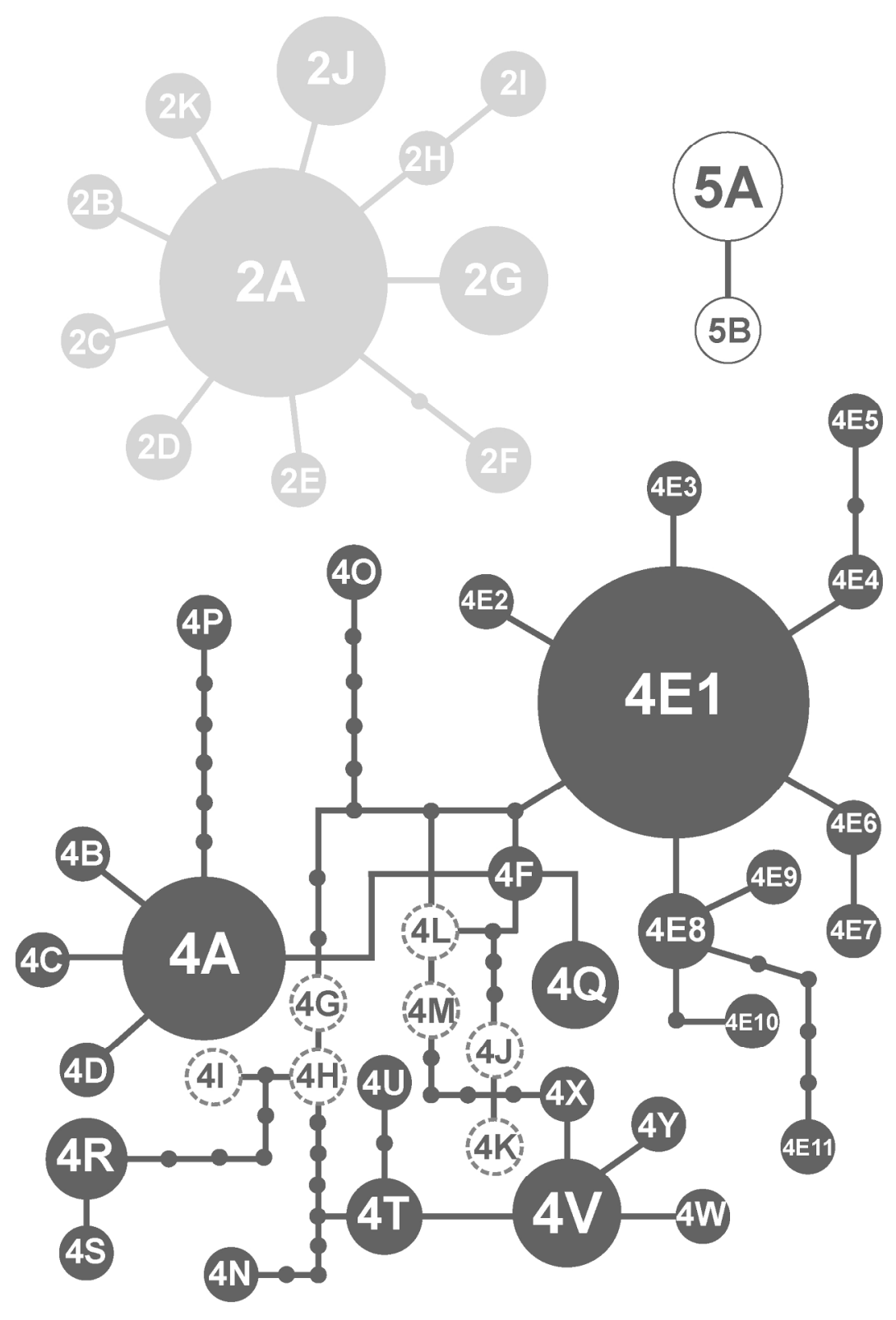

$160 \times 236 \mathrm{~mm}(300 \times 300 \mathrm{DPI})$ 


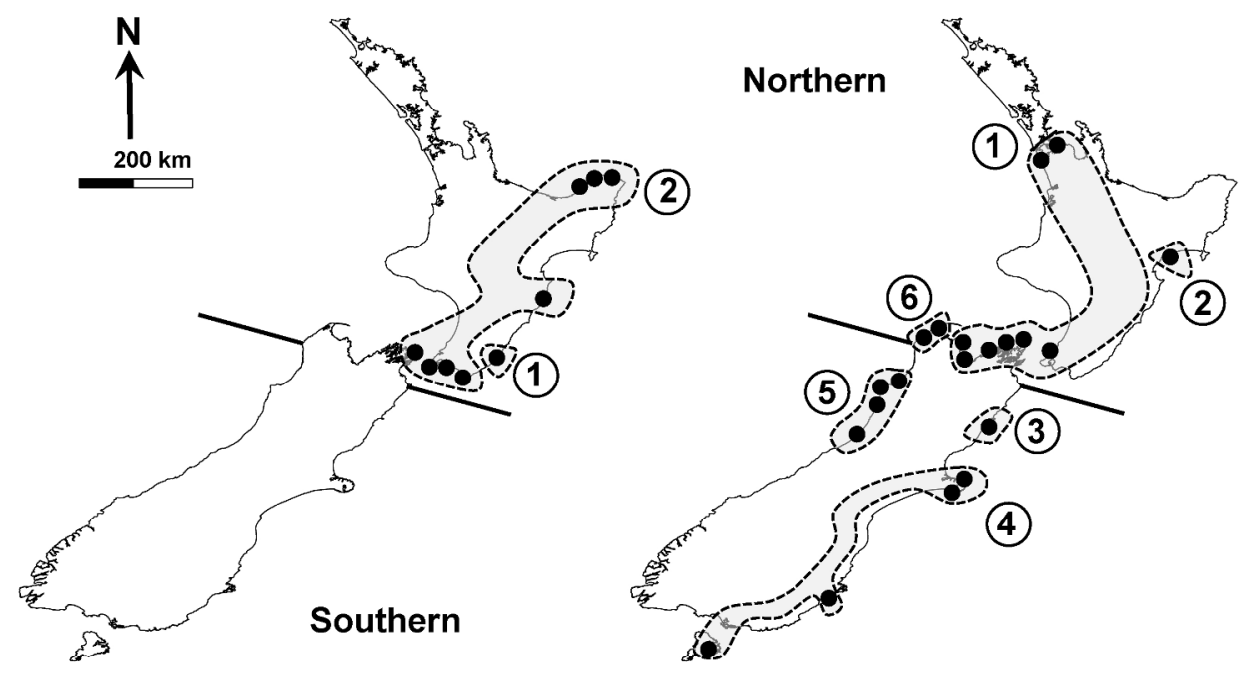

A) Cryptic species N2

B) Cryptic species N4

$240 \times 151 \mathrm{~mm}(300 \times 300 \mathrm{DPI})$ 


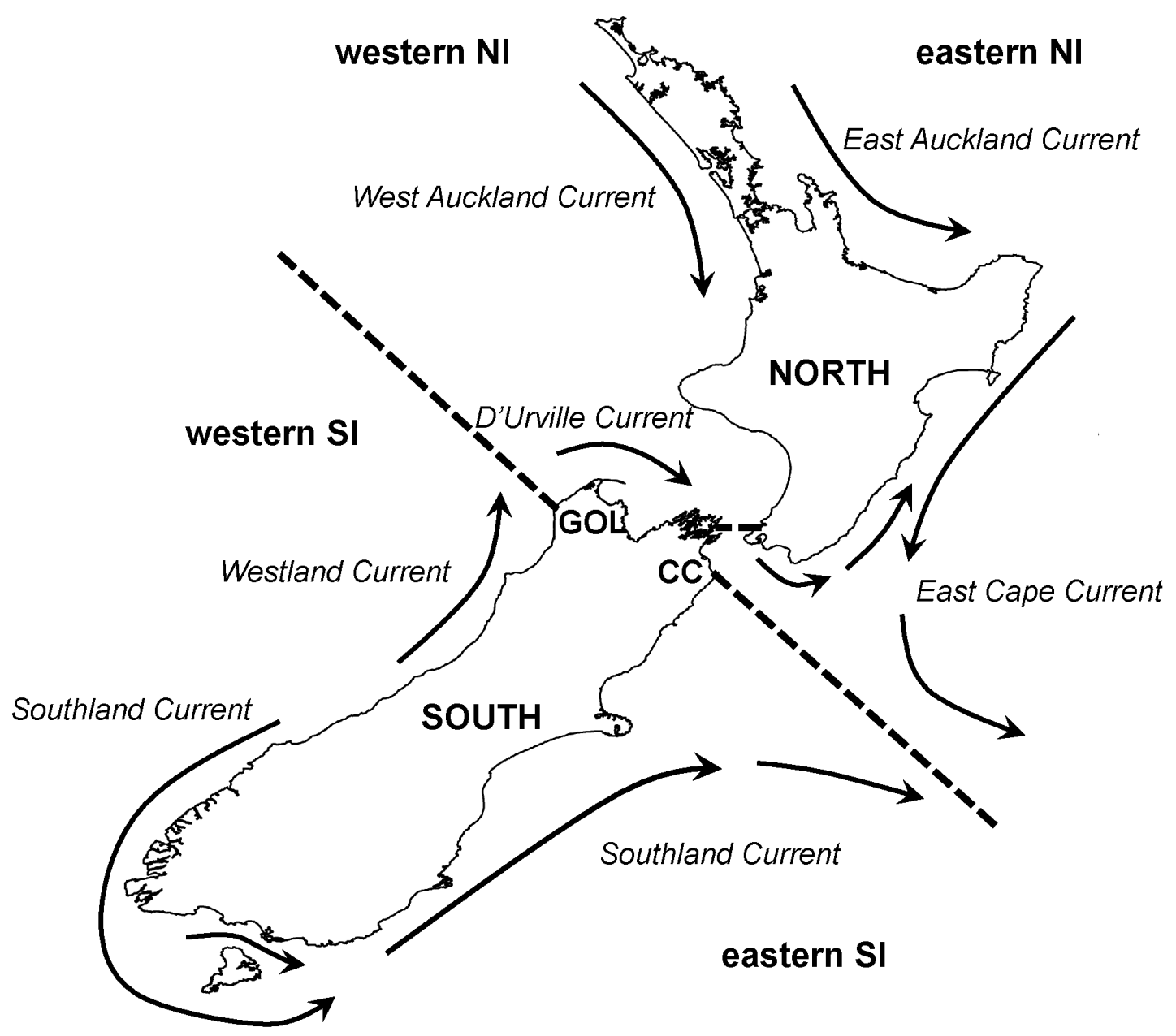

Fig. S1. Map of New Zealand showing regional hydrographic conditions. The north/south and west/east splits described by Apte \& Gardner (2002) and Shears et al. (2008) are separated by dashed line; western NI, western SI, eastern NI and eastern SI. CC: Cape Campbell; GOL: Golden Bay; NI: North Island and SI: South Island. 


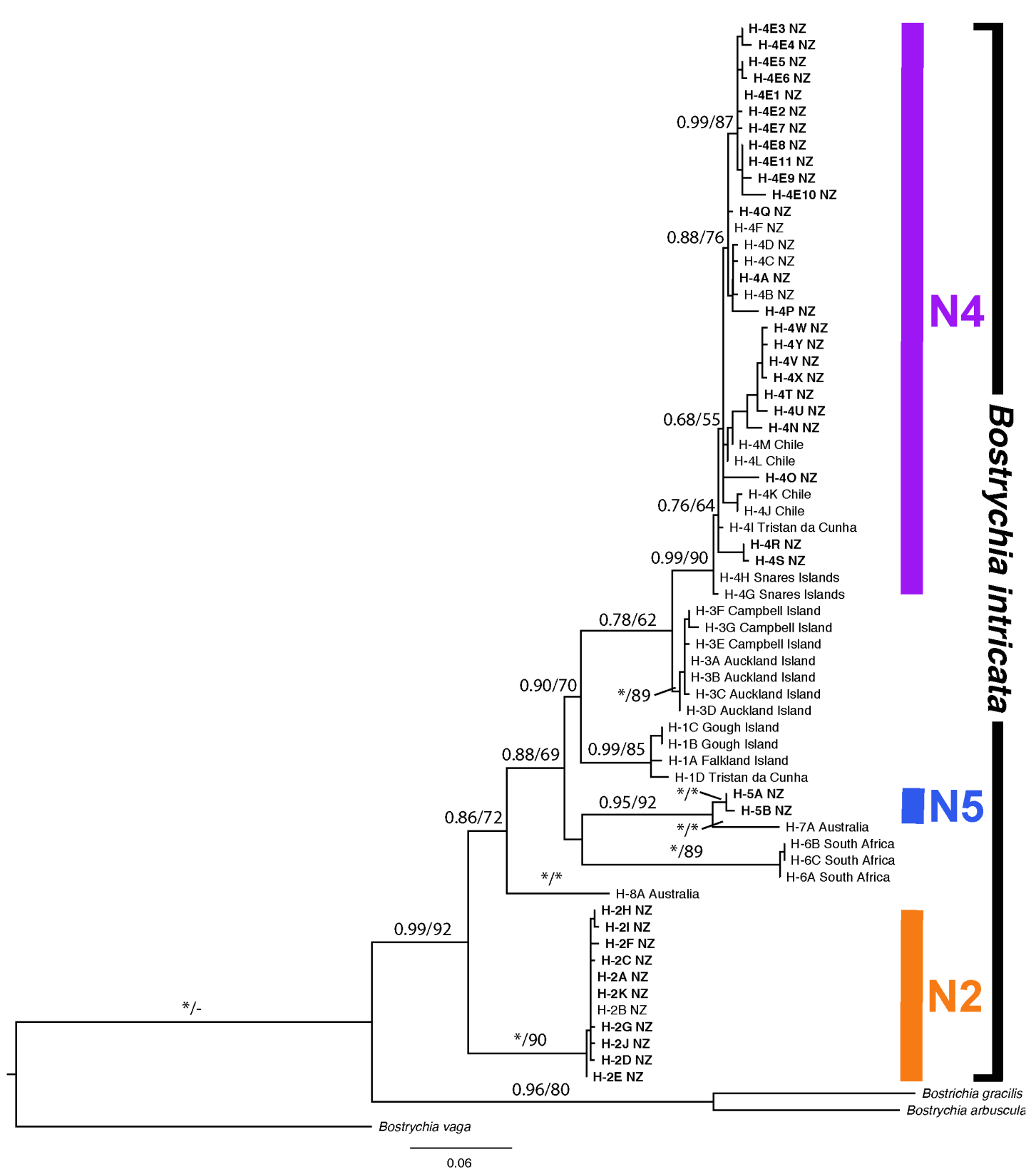

Fig. S2. Phylogenetic tree inferred from Bayesian Inference analyses of COI data set for Bostrychia intricata. Support values at each node are bootstrap values from ML bootstrap (left) and Bayesian Posterior Probability (right). Asterisk (*) indicates full support $(100 \%, 1.0)$ in both analyses and a hyphen (-) indicates no support. Bold letters at each branch tip refer to haplotypes found in this study. H: Haplotype; NZ: New Zealand. 


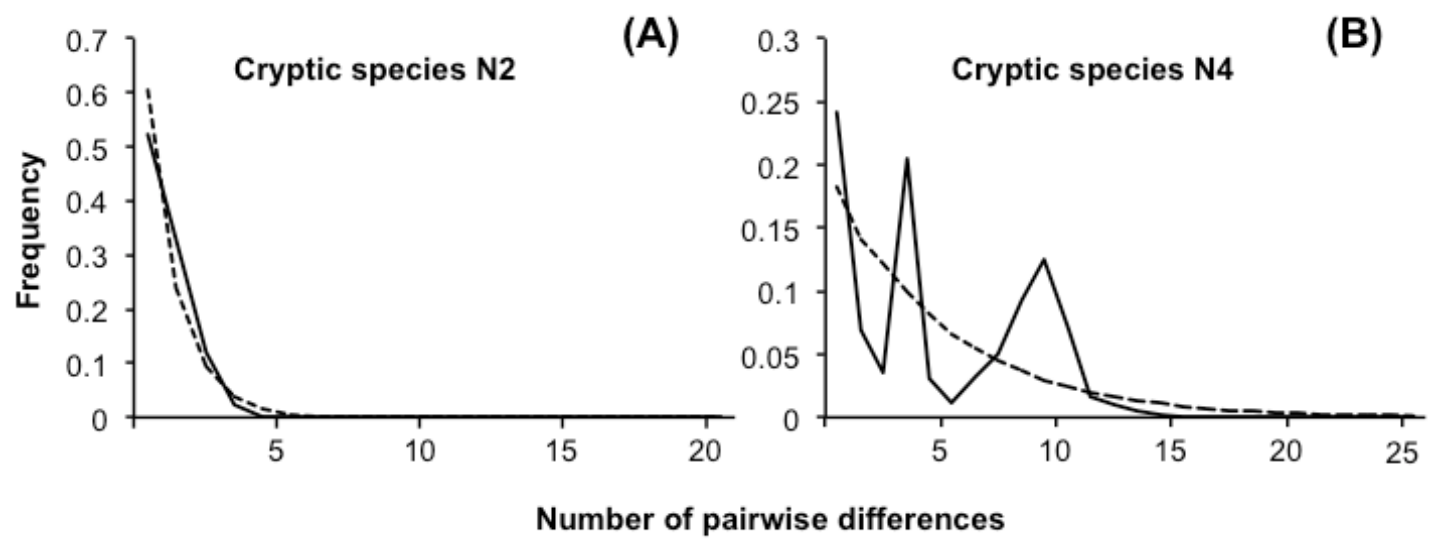

Fig. S3. Mismatch distribution of cryptic Bostrychia intricata species N2 (A) and N4 (B) based on COI sequences. Dashed lines indicate the expected distributions under a recent expansion model, and solid lines indicates the observed distributions. Bold letters at each branch tip refer to haplotypes found in this study. H: Haplotype. 


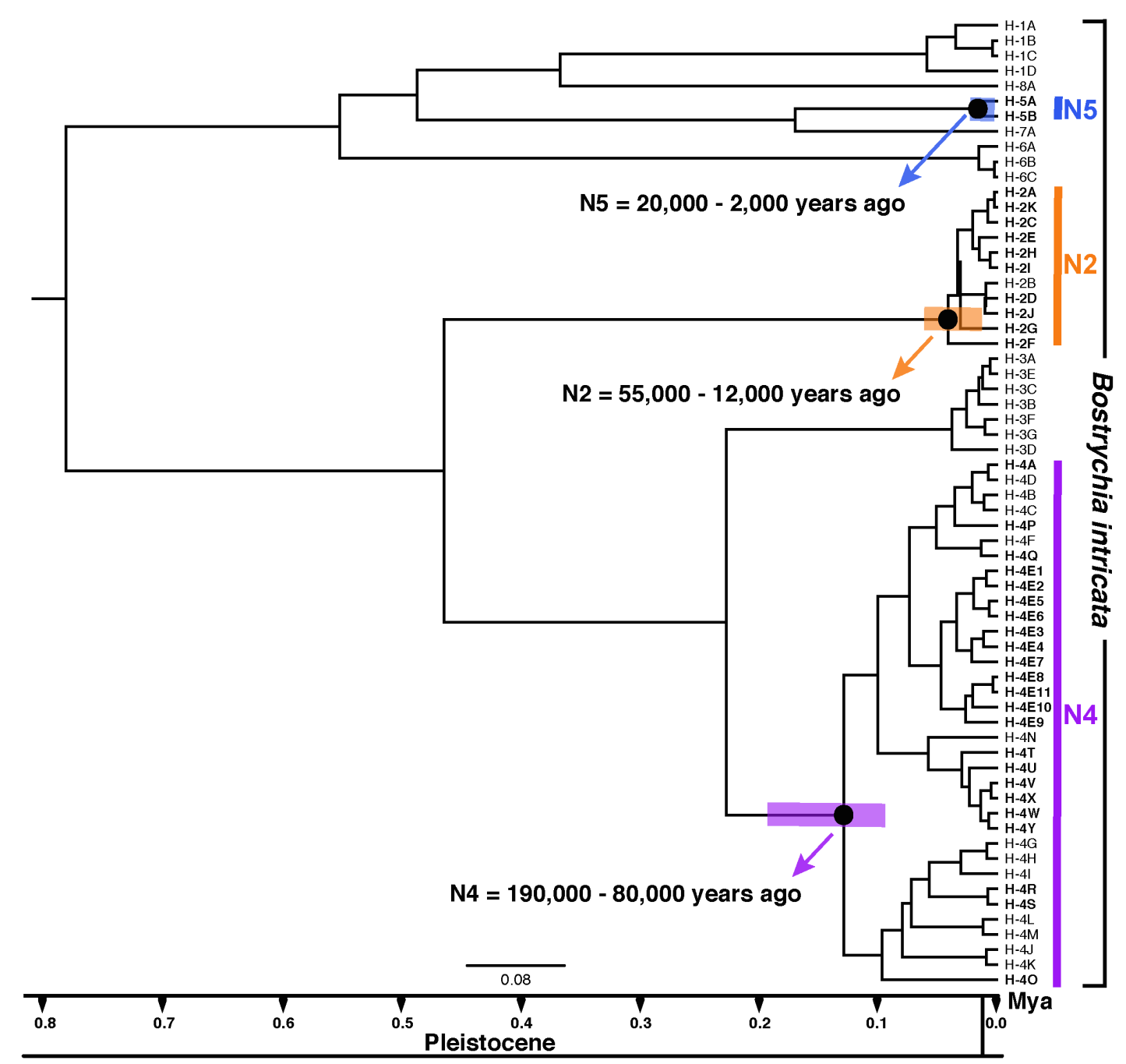

Fig. S4. Bayesian tree for Bostrychia intricata reconstructed using BEAST under a relaxed clock model of the COI sequences. Bars show 95\% highest posterior densities of divergences dates and scale bar are in million years. Black dots at node indicate the support of $>95 \%$ Bayesian posterior probabilities. 
Table S1. Samples used for the phylogenetic analysis, and haplotype network, including location of sample, COI haplotype designation and Genbank Accession Number.

\begin{tabular}{|c|c|c|c|}
\hline Taxon & Location & Haplotype & Accession Number \\
\hline \multirow[t]{14}{*}{ Bostrychia intricata } & Falkland Island & $1 \mathrm{~A}$ & JN881519 \\
\hline & Gough Island & $1 \mathrm{~B}$ & JN881518 \\
\hline & Gough Island & $1 \mathrm{C}$ & JN881517 \\
\hline & Tristan da Cunha & $1 \mathrm{D}$ & JN881516 \\
\hline & Casnell Island, Leigh, North Island, New Zealand & $2 \mathrm{~A}$ & NEW \\
\hline & Moa Point, Wellington, North Island, New Zealand & 2B & JN881543 \\
\hline & Titirangi Bay, Havelock, South Island, New Zealand & $2 \mathrm{C}$ & NEW \\
\hline & Waihau Bay, East Cape, North Island, New Zealand & $2 \mathrm{D}$ & NEW \\
\hline & Porangahua Beach, Hawke Bay, North Island, New Zealand & $2 \mathrm{E}$ & NEW \\
\hline & Castle Point, North Island, New Zealand & $2 \mathrm{~F}$ & NEW \\
\hline & Castle Point, North Island, New Zealand & $2 \mathrm{G}$ & NEW \\
\hline & Cabel Bay, Nelson, South Island, New Zealand & $2 \mathrm{H}$ & NEW \\
\hline & Cabel Bay, Nelson, South Island, New Zealand & 2I & NEW \\
\hline & Red Rock, Wellington, North Island, New Zealand & $2 \mathrm{~J}$ & NEW \\
\hline
\end{tabular}




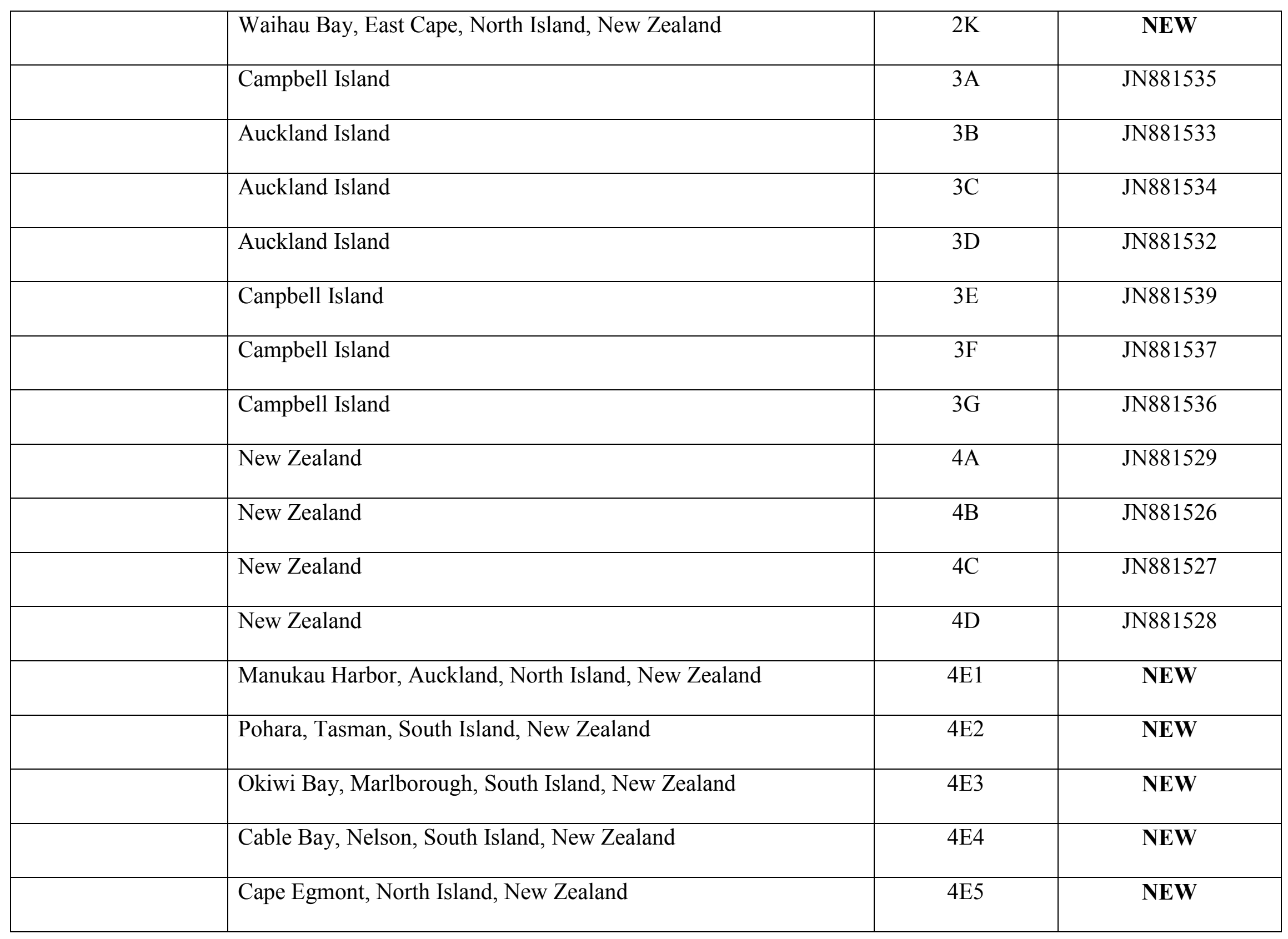




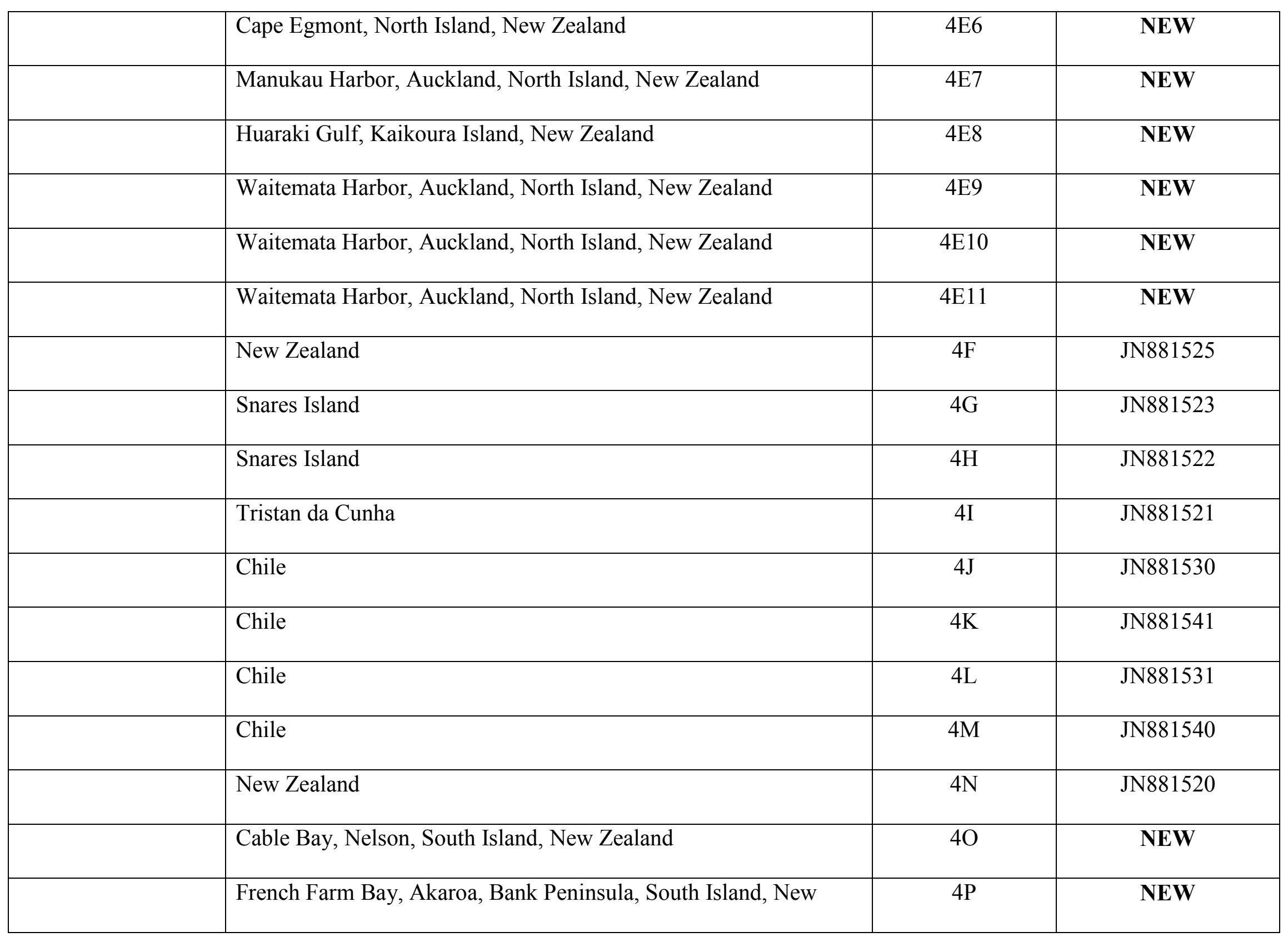




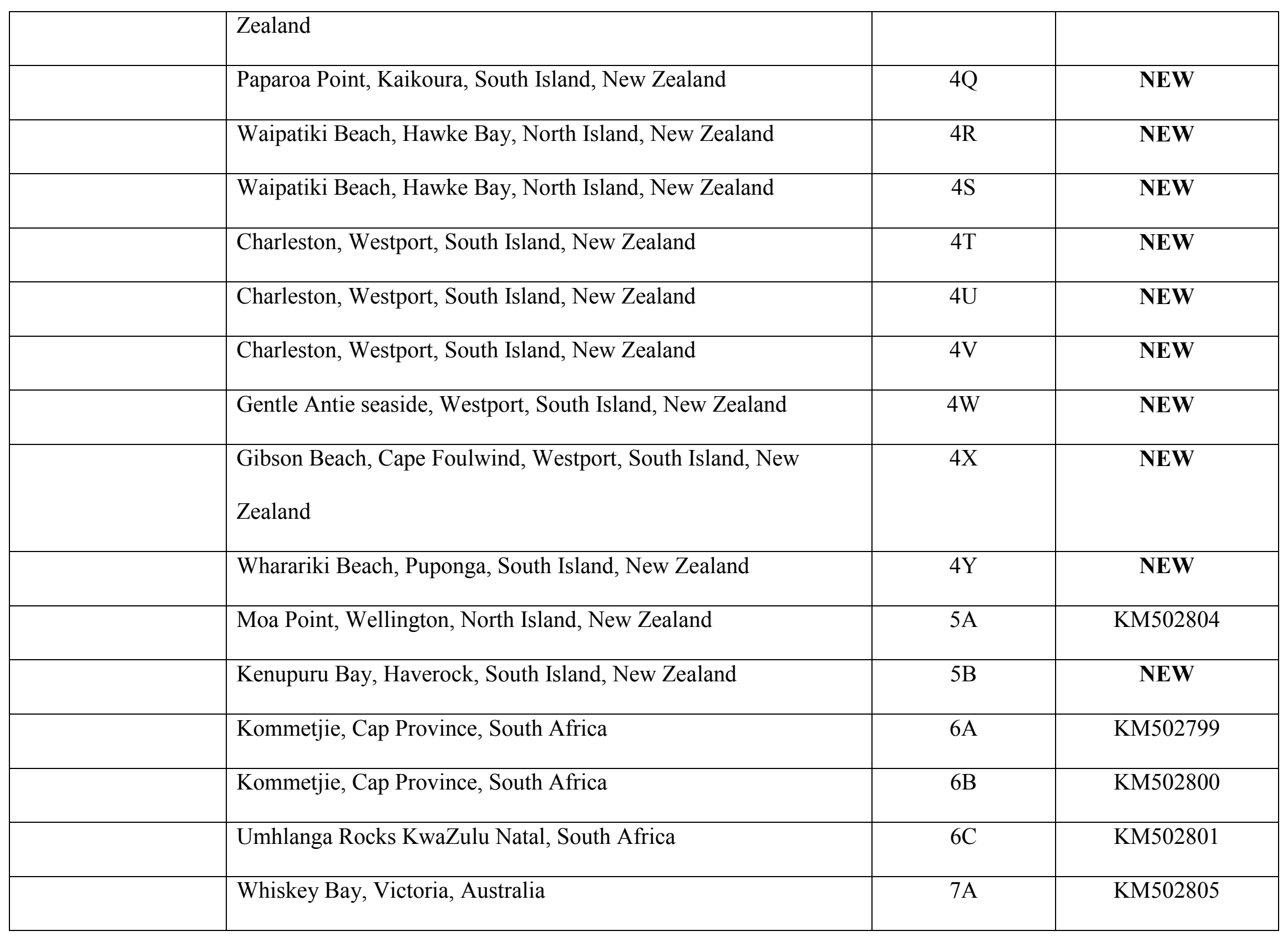




\begin{tabular}{|l|l|c|c|}
\hline & Narooma, New South Wales, Australia & KA & KM502806 \\
\hline Bostrychia gracilis & Taranaki, North Island, New Zealand & KM502798 \\
\hline Bostrychia & Brighton Beach, South Island, New Zealand & KM502795 \\
\hline Bostrychia vaga & Auckland, North Island, New Zealand & & KM502794 \\
\hline
\end{tabular}


Table S2. Population pairwise $F_{\text {st }}$ values estimated from COI sequences of $B$. intricata species N2. Statistical significance $(P<0.05)$ indicated by bold type. For population codes refer to Table1- Figure 1.

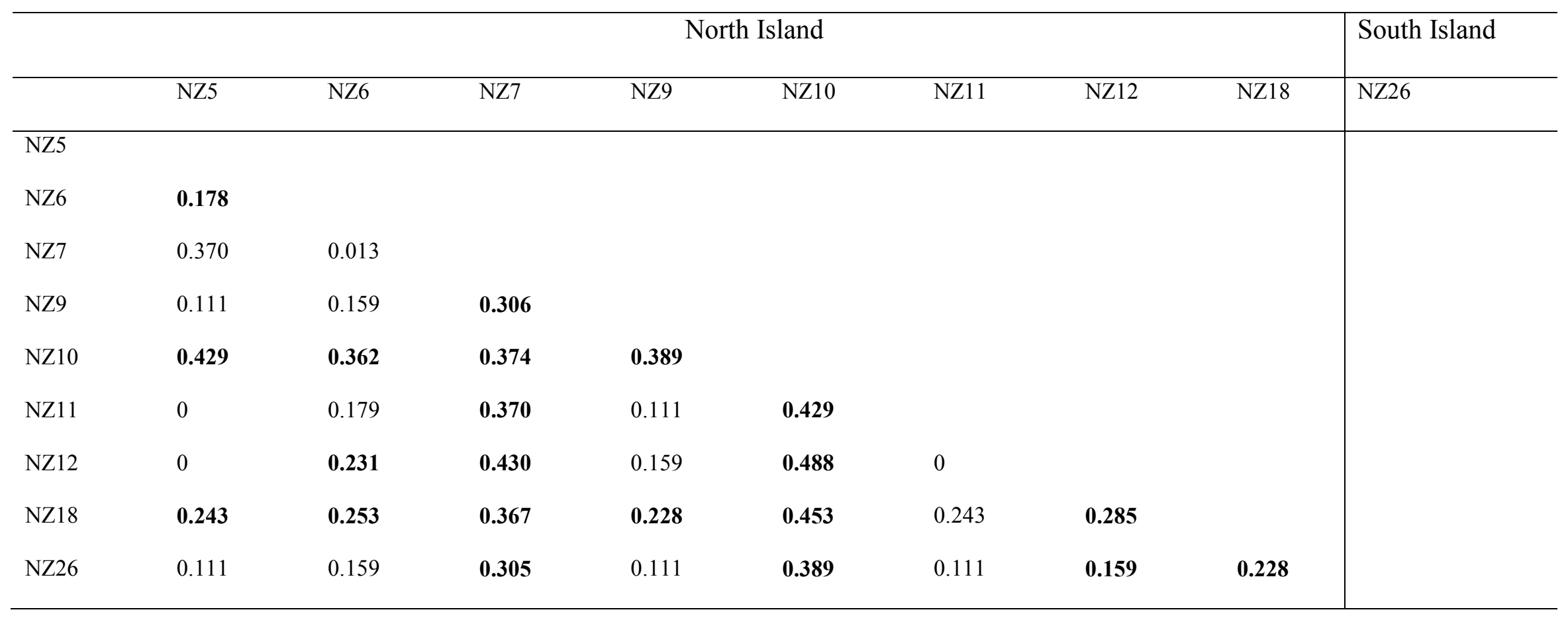


Table S3. Population pairwise $F_{\text {st }}$ values estimated from COI sequences of $B$. intricata species N 4. Statistical significance $(P<0.05)$ indicated by bold type. Population codes refer to Table S1- Figure 1. NI= North Island; SI: South Island.

\begin{tabular}{|c|c|c|c|c|c|c|c|c|c|c|c|c|c|c|c|c|c|c|c|c|c|}
\hline & \multicolumn{2}{|c|}{ Eastern NI } & \multicolumn{8}{|c|}{ Western NI } & \multicolumn{5}{|c|}{ Eastern SI } & \multicolumn{6}{|c|}{ Western SI } \\
\hline & NZ3 & NZ8 & NZ13 & NZ17 & NZ30 & NZ32 & NZ33 & NZ34 & NZ36 & NZ37 & NZ21 & NZ23 & NZ24 & NZ44 & NZ46 & NZ38 & NZ39 & NZ40 & NZ41 & NZ42 & NZ43 \\
\hline NZ3 & & & & & & & & & & & & & & & & & & & & & \\
\hline NZ8 & 0.850 & & & & & & & & & & & & & & & & & & & & \\
\hline NZ13 & 0.370 & 0.948 & & & & & & & & & & & & & & & & & & & \\
\hline NZ17 & 0.437 & 0.981 & 0.136 & & & & & & & & & & & & & & & & & & \\
\hline NZ30 & 0.396 & 0.949 & 0.082 & 0 & & & & & & & & & & & & & & & & & \\
\hline NZ32 & 0.468 & 0.983 & 0.162 & 0 & 0.019 & & & & & & & & & & & & & & & & \\
\hline NZ33 & 0.436 & 0.981 & 0.137 & 0 & 0 & 0 & & & & & & & & & & & & & & & \\
\hline NZ34 & 0.436 & 0.981 & 0.137 & 0 & 0 & 0 & 0 & & & & & & & & & & & & & & \\
\hline NZ36 & 0.453 & 0.982 & 0.150 & 0 & 0.100 & 0 & 0 & 0 & & & & & & & & & & & & & \\
\hline NZ37 & 0.433 & 0.954 & 0.225 & 0.285 & 0.166 & 0.314 & 0.284 & 0.285 & 0.300 & & & & & & & & & & & & \\
\hline NZ21 & 0.723 & 0.978 & 0.904 & 1 & 0.909 & 1 & 1 & 1 & 1 & 0.920 & & & & & & & & & & & \\
\hline NZ23 & 0.591 & 0.915 & 0.698 & 0.778 & 0.909 & 0.796 & 0.777 & 0.777 & 0.787 & 0.719 & 0.257 & & & & & & & & & & \\
\hline NZ24 & 0.417 & 0.828 & 0.386 & 0.417 & 0.370 & 0.448 & 0.416 & 0.433 & 0.433 & 0.412 & 0.433 & 0.006 & & & & & & & & & \\
\hline NZ44 & 0.611 & 0.879 & 0.715 & 0.769 & 0.706 & 0.789 & 0.769 & 0.769 & 0.779 & 0.729 & 0.566 & 0.018 & 0.116 & & & & & & & & \\
\hline NZ46 & 0.618 & 0.912 & 0.753 & 0.828 & 0.748 & 0.845 & 0.828 & 0.828 & 0.837 & 0.771 & 0.418 & 0.051 & 0.111 & 0.021 & & & & & & & \\
\hline NZ38 & 0.826 & 0.956 & 0.926 & 0.960 & 0.927 & 0.960 & 0.960 & 0.960 & 0.962 & 0.933 & 0.955 & 0.878 & 0.784 & 0.817 & 0.825 & & & & & & \\
\hline NZ39 & 0.436 & 0.736 & 0.412 & 0.417 & 0.395 & 0.417 & 0.417 & 0.417 & 0.432 & 0.424 & 0.521 & 0.326 & 0.240 & 0.356 & 0.654 & 0.369 & & & & & \\
\hline NZ40 & 0.873 & 0.984 & 0.968 & 1 & 0.971 & 1 & 1 & 1 & 1 & 0.974 & 1 & 0.929 & 0.840 & 0.875 & 0.924 & 0.814 & 0.535 & & & & \\
\hline NZ41 & 0.846 & 0.967 & 0.943 & 0.975 & 0.944 & 0.975 & 0.975 & 0.974 & 0.976 & 0.949 & 0.972 & 0.889 & 0.798 & 0.881 & 0.821 & 0.484 & 0.427 & 0.821 & & & \\
\hline NZ42 & 0.834 & 0.962 & 0.935 & 0.969 & 0.936 & 0.969 & 0.969 & 0.968 & 0.971 & 0.941 & 0.965 & 0.883 & 0.788 & 0.822 & 0.871 & 0.062 & 0.375 & 0.810 & 0.286 & & \\
\hline NZ43 & 0.818 & 0.947 & 0.916 & 0.949 & 0.917 & 0.945 & 0.949 & 0.949 & 0.952 & 0.923 & 0.942 & 0.866 & 0.775 & 0.802 & 0.855 & 0.064 & 0.362 & 0.771 & 0.444 & 0.054 & \\
\hline
\end{tabular}


 \\ Page 51 of $52 \quad$ Journal of Phycology}

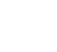

(1)

然

(a) 
Table S4. Analysis of molecular variance (AMOVA) of cryptic species N4 of $B$. intircata from COI sequences. Groups were defined according to four biogeographic regions in NZ, as eastern North Island, western North Island, eastern South Island and western South Island (Table S3). d.f.: degree of freedom. SS: sum of squares.

Asterisk: significant value $P<0.01$.

\begin{tabular}{|c|c|c|c|c|c|}
\hline Source of Variation & d.f. & SS & $\begin{array}{l}\text { Variance } \\
\text { components }\end{array}$ & $\begin{array}{l}\% \\
\text { Variation }\end{array}$ & Fixation indices \\
\hline Among groups & 3 & 343.729 & 2.16704 & 67.57 & $F_{\mathrm{CT}}=0.67579^{*}$ \\
\hline Among populations & 17 & 91.839 & 0.47585 & 14.83 & $F_{\mathrm{SC}}=0.54230^{*}$ \\
\hline Within Populations & 193 & 105.839 & 0.56380 & 17.58 & $F_{\mathrm{ST}}=0.85161 *$ \\
\hline Total & 213 & 541.463 & 3.20669 & & \\
\hline
\end{tabular}

